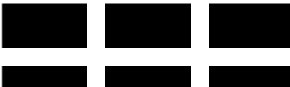 \\ THE WILLIAM DAVIDSON INSTITUTE \\ AT THE UNIVERSITY OF MICHIGAN
}

\section{The Impact of Outward FDI on Home-Country Employment in a Low-Cost Transition Economy}

\author{
By: Jaan Masso, Urmas Varblane and Priit Vahter
}

William Davidson Institute Working Paper Number 873

May 2007 


\title{
The Impact of Outward FDI on Home-Country Employment in a Low-Cost Transition Economy
}

\author{
Jaan Masso, Urmas Varblane, Priit Vahter ${ }^{1}$
}

May 2007

\begin{abstract}
The current extensive literature on the home-country employment effect of FDI focuses almost exclusively on the case of investments from high-income and high labour cost home countries. In our paper we analyse the home-country employment effect in Estonia as a lowcost medium-income transition economy. The data from the population of Estonian firms between 1995 and 2002 was studied with regression analysis and propensity score matching in order to construct an appropriate counterfactual for the firms that have invested abroad. The results indicate that in general, outward FDI had a positive impact on the home-country employment growth. Concerning direct investors (domestic firms investing abroad) and indirect investors (foreign-owned firms investing abroad), the former group had a stronger homecountry employment effect due to their smaller pre-investment size and because the subsidiaries of indirect investors are served from other locations rather than from Estonia. The positive employment effect was much stronger in the case of investments made after 1999 due to the better macro-economic performance of Estonia from the year 2000 onwards. Services firms demonstrated a stronger home-country employment effect than manufacturing firms. Our results imply that the logic of the outward investments from low-cost transition and developing economies differs from that of high-income countries.
\end{abstract}

JEL Classification: D21, F23, J23

Keywords: outward foreign direct investments, employment effects of FDI, Central- and Eastern Europe, transition.

\footnotetext{
${ }^{1}$ Jaan Masso, University of Tartu, Faculty of Economics and Business Administration Narva mnt. 4, Tartu, 51009, Estonia. E-mail: Jaan.Masso@mtk.ut.ee)

Urmas Varblane (corresponding author), University of Tartu, Faculty of Economics and Business Administration, Narva mnt. 4, 51009 Tartu, Estonia. E-mail varblane@mtk.ut.ee, phone +372 7376361 .

Priit Vahter, University of Tartu, Faculty of Economics and Business Administration; School of Economics, University of Nottingham. E-mail: lexpv@nottingham.ac.uk

The authors acknowledge financial support from the EU 6th framework project CIT5-CT-028519 "U-Know", the Estonian Science Foundation grants 5840, 6493 and 6853, and the Estonian Ministry of Education and Research's target funding projects SF0182588s03 and SF0182588s03. We thank for comments Marit Hinnosaar, Tõnu Roolaht and participants of seminars in Brighton (UK) and Pärnu (Estonia), particularly Jutta Günther and Jaanika Meriküll. We solely are responsible for all errors and omissions.
} 


\section{Non-technical summary}

The impact of outward foreign direct investments on the home economy has attracted researchers' attention already for a couple of decades and there has been established an extensive literature on the home-country employment effects of FDI. However, this literature focuses almost exclusively on the case of investments from high-income and high labour cost home countries. An important motivation behind the majority of the previous studies was the attempt to find an answer to the widely spread fear of policy-makers and labour organizations that foreign direct investment, especially those made in the developing and transition countries, will replace the home country's production and exports, and consequently will lead to reduction of employment at home. On the other hand, in our paper we analyse the homecountry employment effect in Estonia as a low- cost medium-income transition economy. The push and pull factors of outward investments from catching up economies are dissimilar to those of the investments from high-income countries. There are relatively few cases of FDI from catching up countries to high-income economies and the major target countries are the ones with a similar or lower level of economic development. Therefore, in the case of FDI from the catching up countries, the labour cost levels of the host and home countries are rather similar. Thus, rather than getting access to cheap labour resources, the main reasons for establishing foreign affiliates are market-related factors, better access to international channels of distribution, and better methods of conducting business in the transitional high-risk environment. Because the vertical FDI would not be used extensively due to the small wage differential between the host and home countries of FDI, and the horizontal investments are mostly in the non-tradable sectors like services (so that production in foreign affiliates cannot substitute for home country exports), short-run job losses in the home country due to outward FDI are rather unlikely.

The firm-level panel dataset we use combines the Estonian Business Register balance sheet and income statement data of all Estonian firms with the dataset from the Bank of Estonia on firms that have outward FDI. Our dataset covers the years 1995-2002. In the course of the analysis, we first calculated simple indicators on the firm-level employment change at home after the undertaking of the outward investment. Secondly, we studied the determinants of firm-level employment growth with regression analysis. Thirdly, the impact of outward FDI on employment at home was estimated with the propensity score matching in order to construct an appropriate counterfactual for the firms that have invested abroad. In other words, 
the aim of the latter approach is to give an estimate to the employment change of the investing firms in case they would not have invested abroad. For that purpose, the firms with outward FDI are compared to those firms without outward FDI that are as similar as possible to the first group in their observed characteristics. Thus, the impact of the outward FDI on the investing firm's employment at home is revealed by the difference between two indicators, these are the actual employment change of the investing enterprise after the investment and the estimated employment change in case of no foreign in investments were maid.

The results of the analysis indicate that in general, outward FDI had a positive impact on the investing firms' employment in Estonia. Concerning direct investors (domestic firms investing abroad) and indirect investors (foreign-owned firms investing abroad), the former group had a stronger home-country employment effect due to their smaller pre-investment size and because the subsidiaries of indirect investors are served from other locations rather than from Estonia (for instance from the country of origin of the parent company). The positive employment effect was much stronger in the case of investments made after 1999 due to the better macro-economic performance of Estonia from the year 2000 onwards. Services firms demonstrated a stronger home-country employment effect than manufacturing firms, because due to the non-tradable nature of services the production in foreign affiliates cannot substitute for the home-country production or home- country exports. The second reason is the smaller size of services firms before the investment (after the investments extra jobs need to be created in order to serve the investments).

Our results imply that the logic of the outward investments from low-cost transition and developing economies differs from that of high-income countries. The results of our study imply for economic policy that there is no ground for fears about job losses at home when firms in low-cost countries establish affiliates in other countries. On the contrary, especially in the case of investments by domestically owned firms quite strong job creation is expected at home after investment. Given that, in such conditions the policy should rather promote than prevent the entry of domestic firms into other markets via direct investments. 


\section{Introduction}

The discussion about the home country effects of foreign direct investment (FDI) has reemerged in a new form. Until recently, outward foreign direct investment (OFDI) was mainly made by firms originating from high-income economies. But the growing importance of OFDI from the Asian emerging economies and new EU member states in Central and Eastern Europe has created the need to analyse the impact of OFDI on the parent firms from those countries, and more broadly on their home economies.

The current paper concentrates on the impact of outward investments on employment in the home country. That has for some time been among the most sensitive issues for the policy makers and labour organizations in the high-income home economies of investors. The public attitude is highly aware of the risk of losing jobs in their countries to the target countries of outward investments. But the whole logic of outward investments from the relatively low-cost economies could be different and consequently, the employment effect may differ as well. The push and pull factors of outward investments from catching up economies are dissimilar to investments from high-income countries. There are relatively few cases of FDI from catching up countries to high-income economies and the major target countries are the ones with a similar or lower level of economic development (Svetlicic and Jaklic 2003). Therefore, in the case of FDI from the catching up countries, the labour cost levels of the host and home countries are rather similar. Thus, rather than getting access to cheap labour resources, the main reasons for establishing foreign affiliates are market-related factors, better access to international channels of distribution, and better methods of conducting business in the transitional high-risk environment. Because the vertical FDI would not be used extensively due to the small wage differential between the host and home countries of FDI, and the horizontal investments are mostly in the non-tradable sectors like services (so that production in foreign affiliates cannot substitute for home country exports), short-run job losses in the home country due to outward FDI are rather unlikely ${ }^{2}$. Therefore also policy recommendations towards the outward FDI may be different, depending on the economic development level of the investors' home country.

\footnotetext{
${ }^{2}$ In the short run, vertical outward FDI is expected to result in a job loss at home if the labour-intensive operations previously conducted at home are repositioned to other countries. In the long run, however, in the case of vertical investments, the home-country and host-country employment are expected to move together, because the processes of both home and foreign affiliates are needed to produce the final output.
} 
For the above reasons, our paper aims to estimate the impact of outward FDI on the home country employment in the case of Estonia as an example of a medium-income small new EU member state ${ }^{3}$. Our contribution to the existing literature is threefold. Firstly, our paper focuses on the home country employment effect in a catching up economy. The mechanism of home country effects in these economies has been rather weakly explored. Secondly, we analyse the employment effect of outward FDI both in the manufacturing and services sector. Due to data availability, the majority of previous studies have focused on manufacturing, but services appear to play the dominating role in the structure of outward investments not only from Estonia but also from the other new EU member states (Svetlicic and Jaklic 2003). Thirdly, we distinguish between direct investors (domestic firms investing abroad) and indirect investors (foreign-owned firms investing abroad). This is motivated, especially in the case of transition countries, by the fact that that many outward investors are foreign-owned firms; however, in the analyses of home-country effects of employment in general, this distinction seems to have been neglected (one exception being the study by Alzinger and Bellak 1999).

The rest of the paper is organized as follows. The next section reviews the existing literature on the home country employment effects of OFDI. The third section explains the macroeconomic role of inward and outward FDI in Estonia. The fourth section presents specific aspects of the potential impact of FDI on the home-economy employment in a catching-up economy and introduces the research propositions. The fifth section describes the research methods used and the sixth section contains an overview of the used data and a descriptive analysis. The seventh section presents the results of the regression analysis and propensity score matching. The last section concludes with policy implications.

\section{Overview of the existing literature on the home-country em- ployment effect of FDI}

The impact of outward foreign direct investments on the home economy has attracted researchers' attention already for a couple of decades (see a recent literature review in Kokko, 2006, and Appendix 1). An important motivation behind the majority of the previous studies was the attempt to find an answer to the widely spread fear of policy-makers and labour organizations that foreign direct investment, especially those made in the developing and transi-

\footnotetext{
${ }^{3}$ The GDP per capita of Estonia is at the level of $65 \%$ from the EU-25 average (Eurostat, 2007).
} 
tion countries, will replace the home country's production and exports, and consequently will lead to reduction of employment at home ${ }^{4}$. Among the researchers of the home-country effect of FDI, this process has been called "the relocation process", which refers to the outward FDI as a substitute for domestic employment ${ }^{5}$.

When analyzing the home-country employment effect of FDI, it is most important to take into consideration the motives of foreign investors moving abroad. Most widely spread is the distinction between horizontal and vertical FDI. Vertical FDI is made by firms that geographically fragment their production into stages, typically on the basis of factor intensities, exploiting lower factor prices abroad or reducing transactions costs by internalizing upstream or downstream activities (i.e., suppliers, marketing channels) (Ekholm and Markusen 2002; Kokko 2006). If different stages of the production process are characterized by different levels of labour intensity, a reasonable strategy would be to allocate the stages with high labour intensity to countries with low levels of labour costs and the stages requiring lots of skills or capital to high-income countries. With vertical investments, there is a complementarity between a firm's foreign and home operations, because both are needed to produce the good. When one of the activities expands, it accordingly causes the expansion of the other activity (Brainard and Riker 1997 use the term technological synergy). However, in the short run, also substitution between the employment levels at home and abroad may take place if an activity previously conducted at home is relocated abroad (Braconier and Ekholm 1999).

In general, firms following the horizontal FDI model expand and enlarge their existing advantages by moving their activities abroad. Horizontal multinational enterprises (MNEs) are multi-plant firms that seek to exploit their existing advantages and replicate roughly the same activities in many locations. By this model, the major trigger of moving outward is the intention to reap benefits of the market opportunities abroad and use the economies of scale effect.

\footnotetext{
${ }^{4}$ As an example, Navaretti et al. (2006) refer to the case whereby the Regional Development Committee of the European Parliament supported the idea developed by the European Commission to impose penalties on the European firms that received support from the EU but thereafter relocated their production activities outside of the EU. Similar proposals or even decisions have been made by some EU member countries - in Italy firms that had relocated a significant part of their activities abroad, were excluded from public support to exports or foreign investments. Brainard and Riker (1997) point out that many US labour organizations opposed the signing of the NAFTA agreement because of the fear of job loss in the US due to relocation of US plants to Mexico.

${ }^{5}$ It can be called the narrow meaning of relocation. But in addition there exists the broad meaning of relocation, used mainly by economic geographers, that addresses the issues about the differences between firms' strategies for serving domestic and foreign markets through allocating their production to different geographical locations (see e.g., literature survey in Pellenbarg et al. 2000). In our article, we use the term relocation in its narrow meaning.
} 
If the produced good is tradable, we would expect a substitution between foreign and home employment: the firm either exports the good produced at home to other locations or produces it in its foreign affiliates (Braconier and Ekholm 1999). However, in the case of nontradables, no such substitution is possible.

The question whether outward FDI substitutes or complements domestic employment has been the subject of a large number of empirical studies, which can be divided into two major groups on the basis of their findings. The first group consists of mainly earlier studies using aggregate level data - imports, wage level etc. (Sachs and Shatz 1994; Feenstra and Hanson 1996). The other group of studies is based on the cross section or panel data of multinational firms investing abroad ${ }^{6}$. Studies on the home-country employment effect have obtained mixed results. The first group of studies dealing in detail with the employment effect of FDI found a substitution effect between a foreign subsidiary's activity and its parent's employment (Kravis and Lipsey 1988, Brainard and Riker 1997, Braconier and Ekholm 2001, Konings and Murphy 2001, and Cuyvers et al. 2005). Several studies have concluded that substitution occurs between countries with comparable factor endowments, which means that low-wage countries are better employment substitutes for one another than for parent (high-income) economy employment (Brainard and Riker, 1997; Slaughter 2000; Braconier and Ekholm, 2001; Konings and Murphy, 2003; Hansson 2005). Several studies have shown that U.S. multinationals using the vertical FDI model appear to reduce employment at home, relative to production, by allocating labour-intensive stages of their production to their affiliates in developing countries (Brainard and Riker, 1997; Slaughter, 2000; Blomström et al. 1997). Konings and Murphy (2003) also concluded that labour substitution is more likely to take place when factor proportions are different in various locations and vertical FDI prevails.

The second group of empirical works has concluded that the complementary effect prevails, which means that the positive employment effect from a foreign affiliate's activity was detected (Lopez-de-Silanes et al. 1996, Feenstra and Hanson 1996, Lipsey et al. 2000, Markusen 2002). The logic behind this is that the opportunity to invest in a low-cost host country could increase the firm's competitiveness, promote its use of economies of scale, and reduce its costs, which may lead to an increase in home-country employment (i.e., the case of vertical investments). What we seem to be seeing here is - as Ekholm and Markusen (2002) called it

\footnotetext{
${ }^{6}$ See e.g., Kravis and Lipsey (1988), Slaughter (1995), Konings and Murphy (2003), Braconier and Ekholm (2001), etc.
} 
- that a "scale effect" dominates over a "substitution effect" for the parent country's firms and the parent country's employment. It was revealed, for example, in the North American car industry by Lopez-de-Silanes et al. (1996). Research on Japanese firms likewise revealed that their home-country employment is growing by investing abroad (Lipsey et al. 2000). It was explained as the result of allocating labour-intensive production to developing countries, which allows increasing supervisory and ancillary employment at home to service foreign operations. Braunerhjelm and Oxelheim (2000) proposed that in industries based on Swedish raw materials, horizontal outward FDI has a complementary effect on home employment ${ }^{7}$.

Thus the analysis of the employment effect of horizontal and vertical type of investments has produced mixed results. We can summarize that the effect of outward investment on home employment depends at least on eight groups of factors: the motive of investment (horizontal versus vertical); the income gap between the home and host country (North-North, North South, South-South and South-North types of investment - Kokko, 2006); the differences in factor intensities (Braconier and Ekholm 2000); the size of the parent company (Pennings and Sleuwaegen 2000); sector-specific aspects (Braunerhjelm et al. 2005, Oxelheim and Thulin 2005); the home country's labour market regulations (Dewit et al. 2004); the size of the home economy; and access to the global networks (Pennings and Sleuwaegen 2000).

\section{The macroeconomic role of inward and outward FDI in Estonia}

Estonia is a transition economy that has been following an extremely liberal economic policy and implementing radical economic reforms, which has produced rapid economic growth. Estonia is known for having attracted substantial amounts of inward FDI. For instance, in 2005, its ratio of inward FDI stock to the GDP reached 102 per cent (see Table 1).

\footnotetext{
${ }^{7}$ Finally, there also exists a third group of studies providing an interesting combination of the win-win type of employment effect (Feenstra and Hanson, 1996, Markusen, 2002) insisting that outward investments can raise the demand and wages for skilled labour in both the parent and host country. This is the result of the differences in labour demand in both countries. Activities transferred by multinationals to low-cost countries are unskilledlabour intensive from the point of view of the home economy, but skilled-labour intensive from the point of view of the host country. Therefore in this case the outcome may be positive for both countries.
} 
Table 1. The importance of inward and outward FDI in the Estonian economy

\begin{tabular}{lcccccccccc}
\hline Indicator & 1996 & 1997 & 1998 & 1999 & 2000 & 2001 & 2002 & 2003 & 2004 & 2005 \\
\hline Inward FDI stock as \% of GDP & 18.4 & 24.0 & 31.3 & 47.0 & 47.9 & 53.5 & 54.0 & 68.2 & 81.6 & 102.0 \\
\hline $\begin{array}{l}\text { Outward FDI stock as \% of } \\
\text { GDP }\end{array}$ & 2.4 & 4.5 & 3.4 & 5.4 & 4.7 & 7.5 & 8.6 & 10.0 & 11.5 & 15.8 \\
\hline $\begin{array}{l}\text { FDI inflows as \% of gross fixed } \\
\text { capital formation }\end{array}$ & 12.5 & 19.4 & 34.6 & 22.0 & 27.9 & 33.6 & 14.3 & 35.0 & 30.2 & 76.6 \\
\hline $\begin{array}{l}\text { FDI outflows as \% of gross } \\
\text { fixed capital formation }\end{array}$ & 3.3 & 10.1 & 0.4 & 6.1 & 4.4 & 12.6 & 6.5 & 5.8 & 8.4 & 16.1 \\
\hline
\end{tabular}

Source: The authors' calculations based on the data from the Bank of Estonia.

By the inward FDI stock to the GDP ratio (and also by the per capita stock of FDI), Estonia is ranked ahead of other locations for FDI in the Central European region (World Investment Report 2005, 2005). Foreign investments have been used by Estonian firms as a market entry method only since 1996 (see Figure 1). The major difference in behaviour has been between the manufacturing and service sector firms. In the case of manufacturing firms, the outward investments have played a less important role than in the case of firms from the service sector. The Estonian extremely liberal foreign trade policy combined with free trade agreements with all major trading partners has provided Estonian firms with good opportunities to use exports to enter foreign markets. The geographical proximity of major export markets and the production cost advantage of Estonia have been the additional factors for keeping production at home. The role of outward investments of Estonian manufacturing firms was mainly to support the export process by creating different distribution subsidiaries in neighbouring countries $^{8}$.

Investment as a market entry method is, hence, mainly associated with the Estonian service sector. Domestic competition in several services - banking, leasing, real estate, transport has been very strong, supporting relatively quick accumulation of specific assets (professional skills, specialised know-how and customised services) that are needed in providing soft services. However, due to the specific aspects of internationalisation in services, the rapid market growth aimed at by Estonian service providers required direct transfer of their services closer to their foreign customers. Particularly active were Estonian banks, who moved first to Latvia and then to Lithuania. This created the first significant outflow boom in 1997 with outward FDI totalling at EUR 122 million (see Figure 1).

\footnotetext{
${ }^{8}$ That is confirmed by the survey of foreign investors, according to which the investments had a strong effect on the exports of the parent company (Varblane et al. 2003).
} 


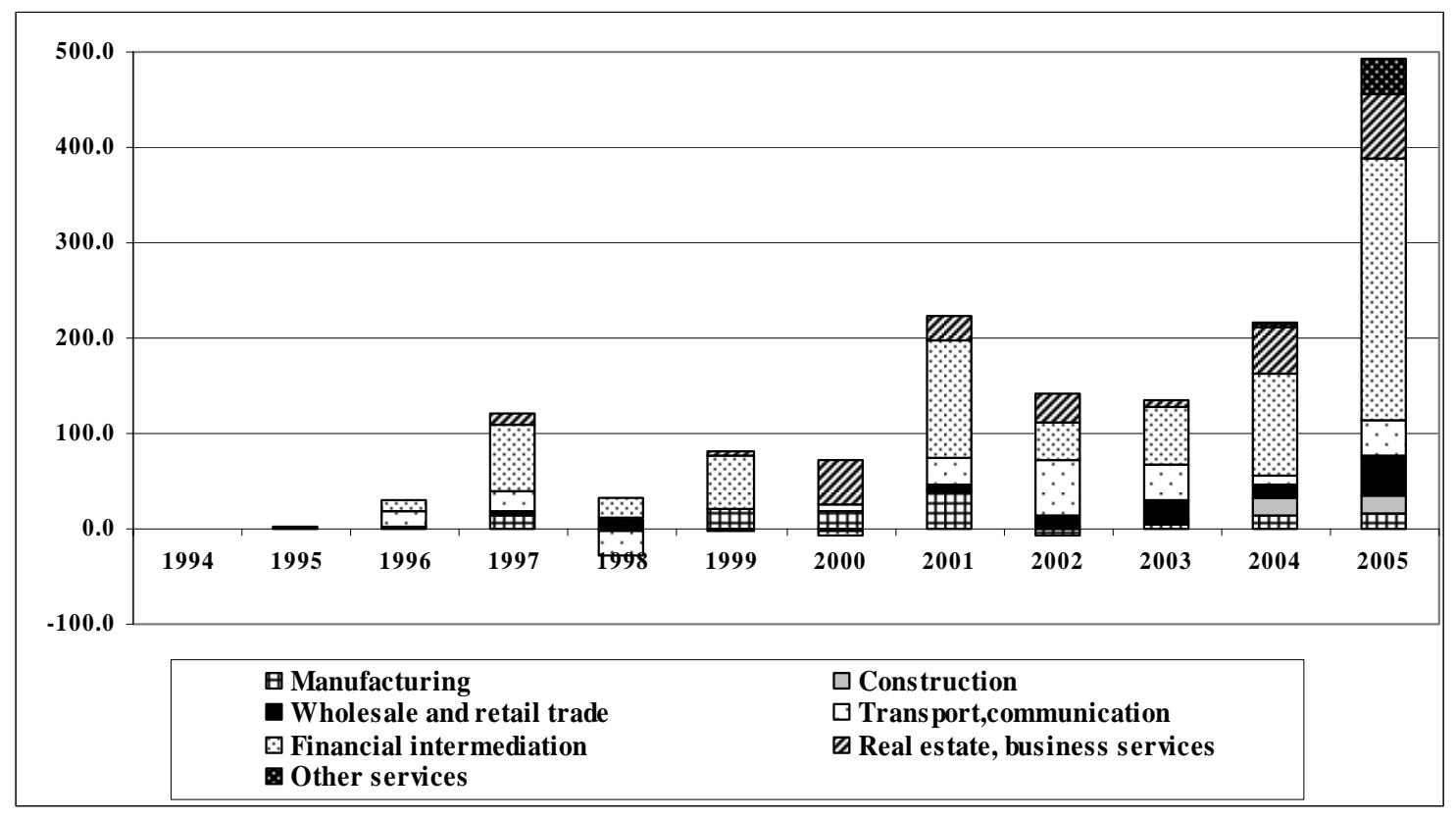

Figure 1. Structure of Estonia's outward FDI in 1994-2005 (annual investments by subgroups in million EUR).

Source: Bank of Estonia.

After the Russian 1998-1999 crisis, a major change occurred in the business strategy of Estonian companies investing abroad. Due to difficulties in their financial situation, the majority of Estonia's outward investors, mainly banks and insurance companies, were acquired by foreign firms. Consequently, Estonian direct outward FDI projects were transformed into indirect ones managed by foreign-owned firms. In addition, direct investors - domestically owned firms in Estonia - reduced their activities in the neighbouring countries, particularly in Russia and Ukraine. A new wave of growth of outward FDI from Estonia gradually started in the year 2000 and peaked in 2005 with $15.8 \%$ of Estonian GDP and $16.1 \%$ of gross fixed capital formation (Table 1), which is the third highest figure among the new EU member states after Cyprus and Malta, and is ahead of other CEE countries (UNCTAD 2007) ${ }^{9}$. Out of all outward investments in 2005, services formed $95 \%$, the major host countries being Latvia and Lithuania. The relatively high role of outward FDI in the Estonian economy and the latter's specific features - a high role of indirect investors and services - explain why Estonia could be an interesting case for studying the home-country effects of FDI made by low-income economies.

\footnotetext{
${ }^{9}$ In 2005, the ratio of the stock of outward FDI to GDP was $28 \%$ in Cyprus, $24 \%$ in Malta,5.3\% in the Czech Republic, $9.3 \%$ in Hungary, and $2.4 \%$ in Poland (own calculations based on data from UNCTAD, Foreign Direct Investment database, and Eurostat).
} 


\section{Research propositions about the home-country employment ef- fect of outward FDI from Estonia as a catching up economy}

The findings about the home-country employment effect of OFDI presented above in the literature review section should be treated with caution as they have been addressed entirely from the point of view of investors coming from high-income economies. Moreover, they cover the period until the late 1990s at best, which means that in the period they study, the process of EU enlargement had not started yet and multinationals from high-income countries had only marginal involvement in Central and Eastern Europe. Therefore conclusions of research results like "relocation of Belgian firms to Central and East European countries does not take place on average and their estimated effects are quite small“" (Konings and Murphy 2003, pp. 11) should be approached with caution as they are looking at the past and fail to consider the dynamic aspect of market entry.

On the basis of surveys that have been reported in a number of studies (e.g., Lankes and Venables 1996, Abraham and Konings 1999) it seems that rather than the low wage costs, the main driving forces for investing in Central and Eastern Europe in the 1990s were the the opportunities to achieve first mover advantages and to get access to a growing market. Thus, the horizontal FDI dominated. Rather than relocation of economic activities to CEE countries, these investments usually implied further growth and job gains in the home firms.

One could expect that the push and pull factors of the outward foreign direct investments from Estonia and other catching up economies are different by comparison with those from high- income countries. Previous research has revealed that there are relatively few cases of horizontal FDI from catching up countries to high-income economies, or the so-called SouthNorth type of investments (Svetlicic and Jaklic 2003). The major target markets for outward investments from the new EU member states are countries with similar or lower levels of economic development, hence we are talking about the South-South type of investments. The likely reason is that domestic firms investing abroad from the catching up economies have only few firm-specific advantages based on technologies, intellectual property, brand names etc. that could be exploited profitably in developed markets (Kokko 2006; Varblane et al. 2003). Rather, the specific competence of those firms lies in their market-specific knowledge 
about the neighbouring catching up economies, their better access to the international channels of distribution, and their better methods of conducting business in the transitional higherrisk environment (Svetlicic and Jaklic 2003). For example, Estonian firms have reported this type of competence from their long-lasting experience in the neighbouring markets of Latvia, Lithuania, Russia and Ukraine (Varblane et al. 2003).

On the other hand, the EU catching up economies have relatively similar levels of production cost and rapidly growing domestic markets. In one of the few previous studies about the impact of outward FDI on Estonia, a survey was conducted among 70 enterprises (Varblane et al. 2001, Table 2). The results indicated quite clearly that the main reasons for establishing foreign affiliates were market related factors rather than getting access to the cheap labour resources. It was explained by the relatively similar level of labour costs in Estonia and the target countries of Estonian outward FDI (mainly the other Baltic States - Latvia and Lithuania). Therefore vertical FDI would not be extensively used, as the wage differential between the home and host country is relatively small.

Table 2. Overview of the results of the surveys of foreign investors on the home-country employment effect in Estonia, 2001

\begin{tabular}{lccccccc}
\hline & Overall & $\begin{array}{c}\text { Direct } \\
\text { investors }\end{array}$ & $\begin{array}{c}\text { Indirect } \\
\text { investors }\end{array}$ & $\begin{array}{c}\text { Manufac- } \\
\text { turing }\end{array}$ & Trade & Finance & Services \\
\hline $\begin{array}{l}\text { Estimation on the success } \\
\text { of investment, \% of re- } \\
\text { spondents }\end{array}$ & 64.6 & 62 & 65 & 60 & 65 & 58 & 72.5 \\
\hline $\begin{array}{l}\text { Effect on employment of } \\
\text { the parent company a) }\end{array}$ & 3.19 & 3.05 & 3.23 & 3.36 & 3.09 & 3.50 & 2.95 \\
\hline $\begin{array}{l}\text { Have you gained access to } \\
\text { cheaper inputs, \% of re- } \\
\text { spondents }\end{array}$ & 32 & 33 & 25 & 36 & 19 & 20 & 41 \\
\hline
\end{tabular}

Source: The authors' calculations based on the survey of foreign investors (see Varblane et al. 2001).

a) On a 5-point scale: 1 - not important...5 - very important.

Another factor emphasized by Varblane et al. (2001) was the relatively low share of the manufacturing sector in the Estonian investments made abroad. This is again very typical of the outward FDI from all Central and East European countries. Because most investments are related to non-tradables (services), among the market entry motives gaining a market share plays a more important role than moving production to locations with cheaper inputs. However, even in manufacturing, the level of labour costs is not an important motive. In addition, in the case of services, following the customers is also a very important motivation for going abroad. Therefore it could be reasonable to expect that the horizontal type of FDI dominates 
and cost reduction as a motive to invest may play a smaller role by outward investments from Estonia. As horizontal investments are mostly in the non-tradable sector like services, the production in foreign affiliates cannot substitute for the home-country production or homecountry exports.

Hence it is reasonable to expect that making horizontal FDI into neighbouring catching up economies is the first stage of foreign market entry by investing from those countries. In general, the expectation is that the complementary effect will prevail, which means that investments abroad will create additional jobs at home. Horizontal FDI into neighbouring catching up economies is likely to help increase the market share in the host country which requires enlarged production at home and thereby facilitates employment growth. Thus, our first research proposition would be as follows.

Proposition 1: Outward investments from Estonia affect home employment positively.

When analysing the home-country effect of outward FDI from Estonia as a representative of catching up economies, the important role of indirect investors should be taken into consideration. In fact, a large part of these countries' outward investments are made by firms which themselves are subsidiaries of foreign companies. We call such investments "indirect FDI" in order to distinguish them from "direct FDI" made by domestic-owned firms (see the discussion about indirect investors in Svetlicic and Jaklic 2003). Any distinction between direct and indirect FDI is justified only if their impact on the home economy differs. Alzinger and Bellak (1999) have shown on the example of Austria that, based on their competitive advantage, these two types of investors develop different entry strategies into Central and Eastern European markets. Foreign-owned firms (indirect FDI) were much more of the horizontal type and used their Austrian affiliates with their specific market know-how as bridgeheads to enter Central European markets. Direct FDI firms, on the other hand, were more of the vertical type and improved their domestic and foreign employment simultaneously by using the internal division of labour. But in their case, the home country was again a high-income economy, which explains the use of vertical FDI by direct investors.

In the case of Estonia, the average size of direct investors investing abroad is smaller than the average size of indirect investors (see footnote 23 ). Due to their generally smaller size, the ability of direct investors to divide and allocate various parts of the value chain activities in various countries seems to be weaker than that of indirect investors; therefore also the home 
job loss due to outward FDI is less likely in the case of the former group. In addition, the relative importance of outward investments for the direct investors is much greater, as they need to control the process of foreign market entry with investments from their home headquarters. It could require employment of additional white-collar workers by Estonian parent companies in order to coordinate the use of distribution channels, sales promotion, advertising, logistics etc. For indirect investors, the situation is different as they may rely on their parent company's resources, nor are they constrained to use only the resources of the subsidiary located in Estonia. A previous study on motivation of outward investments from Estonia also revealed differences between direct and indirect investors (Varblane et al. 2003). Additionally, there is already some evidence from the late 1990s that in conjunction with the growing political and economic stability in Central European transition economies, multinationals from the EU are switching over to the use of more vertical FDI (Radosevic et al. 2003).

All the abovementioned arguments allow us to expect that the impact of outward investments on employment in Estonia differs between indirect and direct investors. As indirect investors could rely more on the global resources of their mother company and their motives may be more orientated towards the vertical FDI, their employment effect in Estonia could be weaker than that of direct investors. Consequently, on the basis of the previous discussion, the following research proposition can be outlined.

Research proposition 2: The employment effect of outward investments differs for direct and indirect foreign investors. The home country employment effect for direct investors is expected to be positive and stronger than that for indirect investors.

However, the employment effect may also be sector-specific and depend on the labour content, skills and technology, or scale intensity of the sector. Currently the impact of OFDI on employment by the service sector is particularly weakly covered. So we intend (and our data allows us) to additionally investigate the effect of relocation in the service sector. The stylized view is that horizontal South-South type of FDI is more commonly found in services like construction and hotels than in manufacturing (Kokko 2006). In catching up economies, the structure of outward FDI is primarily service-oriented and the main target countries have similar or lower income levels. But instead of the traditional expectation that the flows of intermediate inputs in those activities are relatively limited and that production in the home country will benefit relatively little from it, one can expect that investments in services be- 
tween catching up economies may influence home employment positively as well. The size of firms in services in catching up economies is typically rather small, which means that investments into neighbouring economies will require additional white-collar jobs - in order to manage the process of increasing the complexity of service provision. Because services are non-tradable, in case of outward investments in the service sector, the production in foreign affiliates cannot substitute for the production at home and the exports from home to the FDI target countries ${ }^{10}$.

Research proposition 3: The home employment effect of outward investments from Estonia is expected to be stronger in services than in manufacturing.

\section{Framework for the empirical analysis}

We next present our regression model for analyzing the impact of outward and inward FDI on firm-level employment growth. In the existing literature, different approaches have been used for estimating the impact of inward or outward FDI. They can be grouped as follows. First, in some studies the inference is based on the regression of the employment growth at firm level derived from the firm growth model of Jovanovic (1982) and Evans (1987); the independent variables include the firm size, age and other controls (Heshmati 2001). The positive coefficient indicates that firms with inward or outward FDI experience faster than average growth. Secondly, many studies have followed the static labour demand model, where employment depends on the value added and wage (in many cases both in the parent and affiliates) ${ }^{11}$. Both levels and first differenced forms are used. In this case, if the dependent variable is the (growth of) parent employment, the positive coefficient of the outward FDI dummy, or the number of employees in foreign affiliates, indicates that outward FDI increase the labour intensity of the parent's operations (Mariotti et al. 2003). Many studies have focused their inferences about the employment effects of FDI on the elasticities of parent employment to wages in its affiliates and in the parent itself (e.g., Konings and Murphy 2001, Braconier and Ekholm 1999). The positive impact of a foreign affiliate's wage on the home-country employment indicates a substitution effect (production is relocated from the affiliate to the parent if

\footnotetext{
${ }^{10}$ However, nor would we expect a negative effect in manufacturing. Many of the Estonian investments are made to the two other Baltic States - Latvia and Lithuania. Because the markets are small and well integrated, most of the producers have chosen to concentrate their production into one country to achieve economies of scale (Varblane et al. 2001). Thus, the purpose of investing abroad is probably not to start production abroad.

${ }^{11}$ In many studies, the list of independent variables includes just the sales or value added of the parent but not wages (Blomström et al. 1997, Mariotti et al. 2003). The dynamic labour demand model has been used for the analysis of relocation by Bruno and Falzoni (2000).
} 
ceteris paribus the wage level of the affiliate increases), while the negative coefficient of the affiliate's wage indicates that employment in the affiliate and the parent are complementary (because of, for instance, the vertical decomposition of the value chain so that different production stages take place in different locations).

Finally, several studies have considered that similarly to inward FDI also outward FDI is implemented by relatively more successful firms, so that any changes in the firm's performance after undertaking FDI (increased productivity, growth of employment or skill level of labour) need not have been caused by the FDI, but might have occurred in any case, even without the FDI. In this case, FDI is rather a sign of good performance than its ultimate cause. Thus, comparing merely the change in firms' employment growth after becoming MNEs with their earlier employment growth will not give evidence of the causal effects of outward FDI as the firms may have been affected by other factors than FDI. Thus, we would rather be interested in finding an answer to the question, "What would have happened to the firms that invested abroad (the 'treated' firms) if they had not invested (i.e., if they had not received the 'treatment')?" Such an outcome is not observable in case of non-experimental nature of data and is called 'counterfactual'. That selectivity issue is tackled by constructing an appropriate control group for the foreign investment firms from among such firms without foreign investments who are as similar as possible in several dimensions. Usually, propensity score matching is used for that purpose (Barba Navaretti et al. 2006).

Our estimation strategy was driven by the particular data available to us; namely, because the dataset included no exact information on the affiliates in the country where they are located, i.e., we did not know the affiliate's wages, employment, what type it was (whether it was a production or selling unit), etc. Given that, our interpretation of the employment effect of OFDI followed from the sign of the OFDI dummy variable in the regression. Thus, we first estimated the following regression model where the dependent variable is the logarithmic employment growth, $\Delta n_{i, t}=\log N_{i, t}-\log N_{i, t-1}$, where $N_{i, t}$ is the number of employees in firm $i$ at time $t$ and the lower-case letters denote the natural logs of variables, i.e. $n_{i, t}=\log N_{i, t}$. The model of a firm's growth from Jovanovic (1982) and Evans (1987) implies that a firm's growth at time $t$ is a function of its size and age (labelled as $A$, $\left.a_{i, t}=\log A_{i, t}\right)$ at time $t-\tau$, i.e., if we measure a firm's size with its number of employees, then $\Delta n_{i, t}=\ln F\left(A_{i, t-\tau}, N_{i, t-\tau}\right)+u_{i t}$, where $F$ is some twice differentiable function and $u_{i, t}$ is 
the error term. We regress the firm-level employment growth on various firm characteristics (age, size, etc.) lagged by two periods (i.e., $\tau=2$ ). According to Faggio and Konings (2003), this specification is more robust to possible measurement errors in the firm's size (e.g., employment). Using a flexible translog functional form for the function $F($ ) (e.g., the secondorder approximation), the relation can be written down as

(1) $\Delta n_{i, t}=\alpha_{0}+\alpha_{1} n_{i, t-2}+\alpha_{2} n_{i, t-2}^{2}+\alpha_{3} a_{i, t-2}+\alpha_{4} a_{i, t-2}^{2}+\alpha_{5} n_{i, t-2} a_{i, t-2}$.

When adding various other firm-level and industry-level variables that are likely to affect the employment decision as well as various dummies, the equation to be estimated becomes as follows:

$$
\begin{aligned}
& \Delta n_{i, t}=\alpha_{0}+\alpha_{1} n_{i, t-2}+\alpha_{2} n_{i, t-2}^{2}+\alpha_{3} \log a_{i, t-2}+\alpha_{4} a_{i, t-2}^{2}+\alpha_{5} n_{i, t-2} a_{i, t-2}+ \\
& +\alpha_{6} \text { OUTFDI }_{i, t}+\alpha_{7} \text { INFDI }_{i, t}+\alpha_{8} \text { OUTFDI }_{i, t} \times \text { INFDI }_{i, t}+\alpha_{9} \text { STATE }_{i, t}+\beta X_{i, t}+u_{i, t}
\end{aligned}
$$

In this equation, OUTFDI and INFDI are dummies that equal 1 if and only if the firm has respectively made outward FDI or has received inward FDI. The interaction term of the two variables distinguishes the intermediated FDI (indirect FDI) from the outward FDI made by domestic companies (direct FDI). STATE is the dummy for state firms. Thus, the comparison group is domestic private firms without FDI. We note that we do not include in the equation the change in the firm's output, thus the value of the dummy for outward investment indicates the effect on the parent's employment growth; otherwise, if the parent's output growth were included, the OFDI parameter would show the impact of OFDI on the change of the parent's labour intensity. The vector $X_{i, t}=\left(Z_{i, t}, I_{i}, T_{t}, R_{i}\right)$ includes the vector of firm-level variables $\left(Z_{i, t}\right)$, dummies for 1-digit industries $\left(I_{i}\right)$, years $\left(T_{t}\right)$ and 5 geographical regions of Estonia $\left(R_{i}\right)$, while $u_{i, t}$ is the error term. The vector of firm-level variables $Z_{i, t}$ includes the dummy for exports, the log of average labour costs per employee, the log of labour productivity calculated as the ratio of value added (sales minus intermediate inputs) to the number of employees $^{12}$ and capital intensity ( $\log$ of the ratio of fixed capital ratio to the number of employees). The definitions of the variables can also be found in Appendix 2.

When implementing our estimations, we considered different estimation issues. Firstly, in order to control for the entry into and exit from the sample, a 2-step selection model was also estimated in order to control for the selection bias resulting from the non-random entry and

\footnotetext{
${ }^{12}$ This particular measure of labour productivity is preferable to the more commonly used ratio of sales per employee, since we have in our sample firms from different economic sectors.
} 
exit ${ }^{13}$. Given that, our dataset includes the population of Estonian firms, the inclusions in and exclusions from the sample being due to "true" entry and exit, while in other studies the selection bias has also been due to the construction of the sample, e.g., the application of size threshold to the firms to be included in the sample (Heshmati 2001). In our case, controlling for the entry and exit is motivated by the stylized fact that a firms' survival probabilities depend on such characteristics as its age, size, etc. Therefore an analysis of the growth rate based only on surviving firms would give biased results. In the $1^{\text {st }}$ step, the firm's survival model was estimated as $z^{*}{ }_{i, t}=\gamma w_{i, t}+\eta_{i, t}$, where $\gamma$ is the vector of parameters, $w_{i, t}$ is the vector of explanatory variables, $\eta_{i, t}$ is the error term and $z^{*}{ }_{i, t}$ is a latent variable; $\Delta n_{i, t}$ is observable only in cases when $z^{*}{ }_{i, t}>0$. Then, using the estimated parameter values, the inverted Mill's ratio was calculated. The inverse Mill's ratio was then added to the regression that included only the surviving firms (i.e., those observed both at time $t$ and $t-2$; i.e., without entrants and exits). Another estimation issue we needed to solve was how to reduce the estimation results being impacted by a small number of outliers that are likely to exist in firmlevel micro data. For that purpose we used the robust regression analysis ${ }^{14}$.

In order to infer more about the possible causal effects, besides the regression analysis, we also use propensity score matching. The fundamental problem in the evaluation literature is that the counterfactual outcome - in our paper, the case if a firm had not invested abroad - is not observable. However, we can try to construct a control group that is as similar as possible to the outward investors (the treatment group) before the treatment. Inevitably, due to the nonexperimental nature of our data, this is not a true counterfactual but simply a step that allows us to go a bit beyond a simple comparison of means, or a simple least squares regression analysis. Note that not all firms without foreign affiliates are suitable for such a comparison group, because the selection into outward FDI is likely to be non-random. Comparing the change in employment of those firms that undertook outward FDI with that of all non-OFDI firms need not show causal effects, as these groups differed significantly even before the time of investment. We do not know if these differences after undertaking FDI by the first group are due to being a firm with or without foreign affiliates, or due to some other observable or

\footnotetext{
${ }^{13}$ For earlier estimations of this kind, see, for example, Heshmati (2001).

${ }^{14}$ The robust regression begins by fitting the regression, calculating Cook's D statistic and excluding any observation with $\mathrm{D}$ larger than 1 . Thereafter an iterative procedure is applied, by which case weights are calculated on the basis of absolute residuals and regression is run again using these weights; the procedure stops when the weights converge (StataCorp 2003). In the probit model, the possible impact of a small number of outliers on the results was considered by excluding from the dataset observations that fell below the lower $0.5 \%$ percentile or above the $99.5 \%$ percentile of the size distribution of the continuous independent variables.
} 
unobservable characteristics of the firm (size, managerial excellence, etc). Thus, in estimating the effects of FDI, the regression approach based on OLS or other simple techniques may lead to misleading conclusions. There may be a well-known endogeneity problem in this specification used above that the explanatory variable $O U T F D I_{i, t}$ above is correlated with the error term (Smarzynska Javorcik 2004, Smarzynska Javorcik and Arnold 2005). This results in inconsistent estimate of the effect of engaging in outward FDI in case of OLS. One possible partial remedy would be to use the instrumental variable approach. However, good instruments for FDI decisions are hard to find. A useful alternative to the regression approach is the matching approach, or more precisely, propensity score matching (PSM) (Rosenbaum and Rubin 1983, Caliendo and Kopeinig 2005). There is an increasing number of papers addressing the effects of FDI by using the PSM (e.g., Barba Navaretti and Castellani 2004, Huttunen 2005).

The core idea of PSM is that the bias due to differences in the characteristics of the OFDI and non-OFDI group is reduced if the comparison of outcomes (in our case, change in employment) is made by using firms that have invested abroad and a control group of national firms which are as similar as possible to the later MNEs (firms with OFDI) in their observed characteristics, gathered in vector $X$, before the first group's firms became multinational. The PSM method gives a way to summarize a number of characteristics of firms into a single variable indicating the probability of making outward FDI, or the propensity score. The propensity score is estimated by using a probit model where the dependent variable is a dummy variable (at time $t$ ) indicating new outward investors $\left(N E W O U T F D I_{i, t}\right)^{15}$ and independent variables are included in the abovementioned vector of observable variables $X_{i, t-1}$ (at time $t-1^{16}$ ) that may affect the choice of investing abroad:

\section{( 3) $P\left(\right.$ NEWOUTFDI $\left._{i, t}=1\right)=F\left(X_{i, t-1}\right)$}

This new variable is computed both for the firms switching from the status of 'national' to 'multinational' and for the firms that stay 'national'. Then each new multinational firm is paired with its nearest neighbour(s) among the national firms in terms of the propensity score.

\footnotetext{
${ }^{15}$ It means that we focus only on the first time when an investment in a foreign country is made, leaving out the cases when an additional investment is made into another location. The earlier papers seem to have followed the same approach. Secondly, some earlier papers have analyzed the case of multiple treatments where there are more than 2 outcomes, e.g., not investing, investing in developing countries, and investing in developed countries. Multinomial logit is used in this case to derive the propensity scores (Barba-Navaretti et al. 2006).

${ }^{16}$ In the probit model, the possible impact of a small number of outliers on the results was considered by excluding from the dataset observations that fell below the lower $0.5 \%$ percentile or were above the $99.5 \%$ percentile of the size distribution of the continuous independent variables.
} 
In this way, the counterfactual 'what if' has been built. Different matching algorithms have been proposed. We use the nearest neighbour matching (the treated firm is matched with that firm from the comparison group that is closest in terms of propensity score) and Kernel matching algorithm (weighted averages of all firms in the comparison group are used to construct the counterfactual ${ }^{17}$ ).

Then, as a following step, the average treatment effect on treated (ATT) is calculated (Caliendo and Kopeinig 2005), which can be written down as

(4) $A T T_{P S M}=\overline{\Delta^{s} n_{t+s}^{\text {treated }}}-\overline{\Delta^{s} n_{t+s}^{\text {control }}}$,

where the first term on the right-hand side is the mean employment growth of treated firms (new multinationals) and the second term is a weighted mean of employment growth for the counterfactuals over the same period of time. The symbol $s$ denotes the time over which the employment change is calculated (e.g. $\left.\Delta^{2} n_{t+2}=n_{t+2}-n_{t}\right)$.

Arnold and Javorcik (2006) also ensured that the matched control observations came from the same industry and year. Indeed, we might wish the control observations to be from the same year, for instance, due to changing macroeconomic conditions; it is also reasonable to expect that manufacturing firms are matched with other manufacturing firms, not with firms from other sectors. We did not use the approach of Arnold and Javorcik (2003). Instead, we implemented matching in a panel, and controlled for time and sector dummies in the propensity score estimation. In this way, we indirectly controlled for years and sectors in the matching ${ }^{18}$. As a robustness check, we also implemented the matching and calculation of ATT separately year by year, and separately for the manufacturing and services sectors. However, the number of treatment observations (firms with new outward FDI) is not really large enough in any distinct year. For the implementation of the propensity score matching we used the program psmatch2 by Leuven and Sianesi (2003).

\section{Data description and preliminary data analysis}

The firm-level panel dataset we use combines the Estonian Business Register balance sheet and income statement data of all Estonian firms with the dataset from the Bank of Estonia on firms that have outward FDI. Our dataset covers the years 1995-2002 and has information about the whole population of Estonian firms - that is, of up to 41,000 firms per year, includ-

\footnotetext{
17 In case of Kernel matching, the Epanechnikov kernel has been used, the bandwidth having been set at 0.06.

${ }^{18}$ We thank Holger Görg from the University of Nottingham for discussions on these issues.
} 
ing the primary sector, manufacturing, construction and services. Our panel data also includes information about the type of ownership and the presence of outward investments, which allows us to distinguish between four main types of firms in Estonia:

a) domestically owned firms that have not invested abroad;

b) domestically owned firms that have invested abroad (direct investors);

c) foreign-owned firms that have not invested abroad from Estonia;

d) foreign-owned firms that have invested abroad from Estonia (indirect investors).

Many of the previous studies on the home country effect of FDI have had access to better data including also more detailed information on the affiliates, e.g., the employment and wages in affiliates at different locations (Braconier and Ekholm 1999, Konings and Murphy 2001). We can basically calculate just a foreign investment dummy variable. However, the uniqueness of our dataset is that it originates from a low-cost (middle-income) transition economy, while in previous studies the parents have always been from relatively high-income countries.

The descriptive statistics of the variables used in the regression analysis are presented in Appendix 2. We can notice rather large variation of the firm-level employment growth relative to its mean value. This means that the growth rates of individual firms differ remarkably and an individual firm's performances are very idiosyncratic (even in declining industries there are growing firms and vice versa $)^{19}$. The same can be said about the profit-to-sales ratio. About $15 \%$ of the firms in our dataset have at least some exports, $7 \%$ are foreign-owned, and $1 \%$ are state-owned firms. The average annual wage of 2,321 euros per employee indicates a rather low level of labour costs; however, we should mention that this figure is not adjusted for working hours.

Table 3 provides a summary of the Estonian firms' investing status at the beginning, in the middle and at the end of the sample period. The number of firms with direct or indirect outward FDI (second or fourth row respectively inside separate sections of the table) increased during the analysed period (1996-2002) 4.4-fold from 63 to 274 firms. Even in the case of the latter figure we can consider our sample of outward investment firms to be rather small. A major growth occurred among the business service group, where between 1996 and 2002 the number of firms with OFDI increased from 43 to 218. In 2002, 56 outward investors belonged

\footnotetext{
${ }^{19}$ This in reflected in the fact that typically of developed market economies, in each year about $10 \%$ jobs are created and $10 \%$ destroyed, the aggregate net employment growth not being very different from $0 \%$ (Faggio and Konings 2003).
} 
to manufacturing, 11 to construction and 218 to services. The low share of manufacturing firms investing abroad is likely to be the consequence of the relatively small differences in the production cost levels between Estonia and its main host countries of FDI - Latvia and Lithuania $^{20}$. However, the outward investors of the manufacturing industry tend to be larger firms than those of the services sector in terms of the number of their employees based in Estonia (Table 4). Roughly one third of those firms are indirect outward investors and two thirds are direct outward investors. The proportion of direct investors is somewhat lower in manufacturing (59\% of all investors) and higher in construction and services (67-73\%). The relative share of firms with OFDI is still rather low - roughly up to $1 \%$ of all firms.

Table 3. Number of firms by sector, and presence of inward and outward FDI, 19962002

\begin{tabular}{|c|c|c|c|c|c|c|c|c|}
\hline \multirow{2}{*}{$\begin{array}{c}\text { Inward } \\
\text { FDI }\end{array}$} & \multirow{2}{*}{$\begin{array}{c}\text { Outward } \\
\text { FDI }\end{array}$} & \multirow[b]{2}{*}{ Sector } & \multicolumn{3}{|c|}{ Number of firms } & \multicolumn{3}{|c|}{ Per cent of firms } \\
\hline & & & 1996 & 1999 & 2002 & 1995 & 1999 & 2002 \\
\hline No & No & Manufacturing & 3292 & 3712 & 4390 & 91.2 & 88.6 & 88.5 \\
\hline No & Yes & & 15 & 26 & 33 & 0.4 & 0.6 & 0.7 \\
\hline Yes & No & & 296 & 428 & 517 & 8.2 & 10.2 & 10.4 \\
\hline Yes & Yes & & 5 & 24 & 23 & 0.1 & 0.6 & 0.5 \\
\hline No & No & Construction & 1748 & 2089 & 2606 & 97.4 & 97.4 & 97.2 \\
\hline No & Yes & & 6 & 8 & 8 & 0.3 & 0.4 & 0.3 \\
\hline Yes & No & & 40 & 47 & 63 & 2.2 & 2.2 & 2.4 \\
\hline Yes & Yes & & 0 & 1 & 3 & 0 & 0 & 0.1 \\
\hline No & No & Wholesale and retail trade; hotels & 8250 & 10847 & 11703 & 93.5 & 92.9 & 92.1 \\
\hline No & Yes & and restaurants & 18 & 41 & 64 & 0.2 & 0.4 & 0.5 \\
\hline Yes & No & & 553 & 762 & 911 & 6.3 & 6.5 & 7.2 \\
\hline Yes & Yes & & 4 & 20 & 32 & 0 & 0.2 & 0.3 \\
\hline No & No & Transport, storage and communi- & 1424 & 2115 & 2800 & 93.1 & 92.8 & 93.1 \\
\hline No & Yes & cations & 10 & 13 & 21 & 0.7 & 0.6 & 0.7 \\
\hline Yes & No & & 93 & 147 & 177 & 6.1 & 6.4 & 5.9 \\
\hline Yes & Yes & & 2 & 5 & 10 & 0.1 & 0.2 & 0.3 \\
\hline No & No & Financial intermediation, real & 3192 & 5175 & 8356 & 93.9 & 92.2 & 91.7 \\
\hline No & Yes & estate and business services & 7 & 38 & 66 & 0.2 & 0.7 & 0.7 \\
\hline Yes & No & & 200 & 383 & 663 & 5.9 & 6.8 & 7.3 \\
\hline Yes & Yes & & 2 & 17 & 25 & 0.1 & 0.3 & 0.3 \\
\hline
\end{tabular}

Source: The authors' calculations based on the Estonian firm-level panel data $1995-2002$.

In order to get a better understanding about the importance of firms with OFDI in the Estonian economy, Table 4 was constructed. It reveals that the share of firms with OFDI by employment, assets, value added and sales is several times higher than their share by the number

\footnotetext{
${ }^{20}$ In 2002, according to our database, Estonian firms had in total 463 affiliates abroad, of which $182(39 \%)$ were in Latvia and $112(24 \%)$ in Lithuania. The share of affiliates in the EU15 countries was a mere $12.5 \%$. Thus it is also not possible to analyze the effects of the South-South type of investments (the target country is another lowincome country) vis-à-vis the South-North type of investments (the target country is a high-income one), because there simply is not enough variation in the destination country at the moment.
} 
of firms ${ }^{21}$. In manufacturing, $1.2 \%$ of firms had OFDI, but their share in value added was $9 \%$, in sales $-14.3 \%$, in assets $-14 \%$ and in employment $-8.9 \%$. A similar picture emerges in the services. Outward investors have the biggest employment share in transport, storage and communications $(9.3 \%)$, and the share of value added is highest in the manufacturing (9\%) sector. Concerning employment, indirect investors have a higher share in manufacturing and construction, direct investors in services. Consequently, the preliminary analysis of data tells us that firms investing outward are performing better than the domestic market oriented firms; they are better equipped with capital, and their employment is on the average level of the corresponding economic sector. In manufacturing, the shares of exports or imports of outward investors (respectively 12.5 and $12.1 \%$ ) are not very much larger than their share in value added. These numbers are in accordance with the horizontal investments, because in case of vertical investments, we would expect intensive trade flows between the parent and its affiliates.

Table 4. The role of four groups of firms in the Estonian economy in 2002 (\% of the group total)

\begin{tabular}{|c|c|c|c|c|c|c|c|c|}
\hline $\begin{array}{l}\text { Inward } \\
\text { FDI }\end{array}$ & $\begin{array}{l}\text { Outward } \\
\text { FDI }\end{array}$ & Sector & Employees & Sales & $\begin{array}{l}\text { Value } \\
\text { added }\end{array}$ & Assets & Exports & Imports \\
\hline No & No & Manufacturing & 63.9 & 56.1 & 53.8 & 48.6 & 34.8 & 28.2 \\
\hline No & Yes & & 3.9 & 4.5 & 3.5 & 5 & 3.5 & 3.3 \\
\hline Yes & No & & 28.1 & 31.1 & 37.1 & 37.5 & 52.6 & 59.7 \\
\hline Yes & Yes & & 4.2 & 8.3 & 5.5 & 9 & 9.0 & 8.8 \\
\hline No & No & Construction & 89.6 & 77.4 & 88.3 & 71 & 30.9 & 41.5 \\
\hline No & Yes & & 1.9 & 6.1 & 1.4 & 6.9 & 3.7 & 8.5 \\
\hline Yes & No & & 5.9 & 8.3 & 10.2 & 14.1 & 63.4 & 44.5 \\
\hline Yes & Yes & & 2.7 & 8.2 & 0 & 8 & 2.0 & 5.4 \\
\hline No & No & Wholesale and & 82.7 & 67.1 & 69.6 & 63.9 & 60.7 & 53.6 \\
\hline No & Yes & retail trade; & 2.6 & 5.3 & 4.6 & 6.5 & 8.6 & 7.8 \\
\hline Yes & No & hotels and res- & 13.4 & 25.1 & 22.8 & 26.4 & 28.6 & 34.3 \\
\hline Yes & Yes & taurants & 1.3 & 2.4 & 3 & 3.2 & 2.1 & 4.3 \\
\hline No & No & Transport, stor- & 81.7 & 71.6 & 84.9 & 67.7 & 84.5 & 87.1 \\
\hline No & Yes & age and commu- & 8.4 & 12.5 & 5.2 & 21.1 & 8.3 & 5.8 \\
\hline Yes & No & nications & 9.3 & 13.9 & 9.2 & 10.1 & 7.1 & 6.6 \\
\hline Yes & Yes & & 0.7 & 1.9 & 0.6 & 1.2 & 0.1 & 0.5 \\
\hline No & No & Financial inter- & 87.3 & 80.5 & 80.9 & 61.1 & 73.7 & 74.1 \\
\hline No & Yes & mediation; real & 3.4 & 7.3 & 5.4 & 21 & 1.8 & 4.0 \\
\hline Yes & No & estate and busi- & 8.7 & 10.3 & 12.1 & 13 & 23.2 & 20.6 \\
\hline Yes & Yes & ness services & 0.5 & 1.9 & 1.6 & 4.9 & 1.3 & 1.3 \\
\hline
\end{tabular}

As concerns the ranking of the four groups of firms in terms of labour productivity, wages and capital intensity (see Table 5, and Vahter and Masso 2005), both indirect and direct out-

\footnotetext{
${ }^{21}$ Variables used in the analysis, such as output, value added and intermediate inputs are deflated by respective deflators of the system of national accounts provided by the Statistical Office of Estonia.
} 
ward investors outperform both foreign-owned and domestic firms, having 1.5-4-fold higher productivity, wages and capital intensity. Despite the higher level of wages, in manufacturing, the unit labour cost is much lower among outward investors (16\% for direct, $12 \%$ for indirect investors) than among domestic firms (labour costs form $24 \%$ of the sales) or foreign firms $(33 \%)$. A similar pattern appears in the services industries. These numbers are an evidence in favour of the outward investors being relatively successful firms. Although there is some evidence that some foreign-owned firms have located their production in Estonia to take advantage of the cheap labour that seems not to apply so much in the case of outward investors.

Table 5. Labour productivity, wages, capital intensity and unit labour cost in different groups of firms

\begin{tabular}{lllcccc}
\hline Inward & Outward & Labour & Capital & (n) \\
FDI & FDI & Sector & productivity & Wages & intensity & Unit labour cost \\
\hline No & No & Manufacturing & 20.2 & 2.4 & 3.7 & 0.24 \\
No & Yes & & 43.6 & 4.9 & 9 & 0.16 \\
Yes & No & & 39.6 & 4.6 & 12.4 & 0.33 \\
Yes & Yes & & 74 & 6.1 & 16.8 & 0.12 \\
\hline No & No & Construction & 21.5 & 2.3 & 2.6 & 0.20 \\
No & Yes & & 58.9 & 4.4 & 3.5 & 0.16 \\
Yes & No & & 97.4 & 6.7 & 52.6 & 0.27 \\
Yes & Yes & & 100.5 & & 7.1 & \\
\hline No & No & Wholesale and retail & 47.7 & 1.9 & 3.7 & 0.16 \\
No & Yes & trade; hotels and & 216.5 & 5 & 10.4 & 0.08 \\
Yes & No & restaurants & 137.4 & 5.3 & 16.8 & 0.22 \\
Yes & Yes & & 140 & 7.5 & 15.9 & 0.08 \\
\hline No & No & Transport, storage & 23.3 & 1.6 & 9.5 & 0.21 \\
No & Yes & and communications & 256.6 & 6.8 & 26.6 & 0.13 \\
Yes & No & & 78.8 & 4.5 & 11.8 & 0.23 \\
Yes & Yes & & 59.3 & 4.8 & 16.4 & 0.18 \\
\hline No & No & & 19.6 & 3.2 & 37.1 & 0.71 \\
No & Yes & Financial intermedia- & 44.2 & 10.2 & 124.6 & 1.23 \\
Yes & No & tion; real estate and & 33.9 & 7.7 & 91 & 1.59 \\
Yes & Yes & business services & 166.8 & 14.5 & 68 & 0.42 \\
\hline
\end{tabular}

Table 6 presents the results of the employment changes in different groups of Estonian firms. In order to get a better understanding about the dynamics of employment, the data were split into two periods: 1995-1999 and 2000-2002. The first period is associated with the restructuring period in the Estonian economy and it ends with the impact of the Russian crisis. The sec- 
ond period is one of rapid economic growth with extensive use of outward FDI as a market entry method ${ }^{22}$.

Table 6. The annual average employment growth rate of firms with inward or outward FDI

\begin{tabular}{lccccc}
\hline Industry & Period & $\begin{array}{c}\text { No inward } \\
\text { or outward } \\
\text { FDI }\end{array}$ & $\begin{array}{c}\text { Inward } \\
\text { FDI, no } \\
\text { outward } \\
\text { FDI }\end{array}$ & $\begin{array}{c}\text { No inward } \\
\text { FDI, outward } \\
\text { FDI }\end{array}$ & $\begin{array}{c}\text { Inward \& } \\
\text { outward } \\
\text { FDI }\end{array}$ \\
\hline \multirow{2}{*}{ Manufacturing } & & $\begin{array}{c}\text { Domestic } \\
\text { firm }\end{array}$ & $\begin{array}{c}\text { Foreign } \\
\text { firm }\end{array}$ & $\begin{array}{c}\text { Direct inves- } \\
\text { tors }\end{array}$ & $\begin{array}{c}\text { Indirect } \\
\text { investors }\end{array}$ \\
\hline Construction & $1995-99$ & $-0.48 \%$ & $0.26 \%$ & $8.38 \%$ & $-1.51 \%$ \\
\hline Wholesale and retail trade; hotels & $2000-02$ & $2.98 \%$ & $0.82 \%$ & $7.23 \%$ & $6.93 \%$ \\
\cline { 2 - 6 } and restaurants & $1995-99$ & $-2.38 \%$ & $14.43 \%$ & $-0.36 \%$ & $-27.55 \%$ \\
\hline $\begin{array}{l}\text { Transport, storage and communi- } \\
\text { cations }\end{array}$ & $2000-02$ & $2.87 \%$ & $5.49 \%$ & $9.71 \%$ & $-3.29 \%$ \\
\hline Financial intermediation, real & $1995-99$ & $0.25 \%$ & $3.27 \%$ & $8.76 \%$ & $2.75 \%$ \\
\hline estate and business services & $2000-02$ & $4.51 \%$ & $6.21 \%$ & $4.42 \%$ & $-19.86 \%$ \\
\hline
\end{tabular}

The first and most general finding is about the much higher home employment growth of firms performing OFDI (in manufacturing, construction, and trade), which supports our first research proposition (positive impact of outward investment on the parent's employment growth). It could mean that as long as the major host countries of OFDI are the neighbouring countries with relatively similar factor costs, outward investors will not reduce employment in Estonia. The second major finding is about the different behaviour of direct and indirect investors in line with our second research proposition. Direct investors - local firms performing outward investments - in most cases experienced more rapid growth of home employment than indirect investors (the exceptions were the trading firms in the period 2000-2002 and financial intermediation and business services in the period 1995-1999). The third finding concerns the changes in employment growth in the two periods. In all sectors domestic firms increased their number of employees on average more in the second period, thus any differences between the two periods may be linked at least partly to improved general macroeconomic performance in Estonia.

Concerning services, in the wholesale and retail trade, all other categories of firms clearly outperform the domestic firms in employment growth. In transport, storage and communica-

\footnotetext{
${ }^{22}$ The average GDP growth rates in the two periods were respectively $5.1 \%$ and $8.8 \%$ (Source: Bank of Estonia).
} 
tions, indirect investors experience negative employment growth. In financial intermediation, the employment growth of outward investors changes from positive to negative. The negative employment growth for indirect investors may indicate the use of certain elements of vertical FDI, where optimisation occurs between different markets in the framework of the whole value chain of the multinationals.

Next we will look at how employment has changed in firms with outward FDI after they started to invest abroad. Although such calculations are not sufficient for making any causal inferences (see e.g., the discussions in the last section), they provide a useful first look at the data. Table 7 presents the results of the calculations. The last column shows the percentage change in the parent firm's employment relative to its employment in the last year before making the investment.

Table 7 Change in employment after implementing outward FDI, 1995-2002

\begin{tabular}{|c|c|c|c|c|c|c|}
\hline & \multirow{2}{*}{$\begin{array}{l}\text { Year of } \\
\text { outward } \\
\text { FDI }\end{array}$} & \multirow{2}{*}{$\begin{array}{l}\text { Number of } \\
\text { firms used } \\
\text { in calcula- } \\
\text { tions }\end{array}$} & \multicolumn{3}{|c|}{$\begin{array}{l}\text { Percentage of firms where employment } \\
\text { after implementing outward FDI has... }\end{array}$} & \multirow{2}{*}{$\begin{array}{l}\text { Change in the num- } \\
\text { ber of employees } \\
\text { relative to the initial } \\
\text { level, } \%\end{array}$} \\
\hline & & & ..decreased & $\begin{array}{c}. . \text { not } \\
\text { changed }\end{array}$ & ..increased & \\
\hline Total & 1 & 231 & 29.0 & 22.1 & 48.9 & 14.6 \\
\hline \multirow[t]{5}{*}{ sample } & 2 & 114 & 28.1 & 16.7 & 55.3 & 19.5 \\
\hline & 3 & 69 & 27.5 & 13.0 & 59.4 & 25.0 \\
\hline & 4 & 38 & 31.6 & 7.9 & 60.5 & 9.9 \\
\hline & 5 & 15 & 33.3 & 6.7 & 60.0 & 10.6 \\
\hline & 6 & 4 & 50.0 & 0.0 & 50.0 & 195.5 \\
\hline \multicolumn{7}{|c|}{ Year of outward FDI } \\
\hline \multirow[t]{3}{*}{ Until 1999} & 1 & 62 & 35.5 & 9.7 & 54.8 & 13.6 \\
\hline & 2 & 54 & 38.9 & 9.3 & 51.9 & 12.7 \\
\hline & 3 & 47 & 34.0 & 8.5 & 57.4 & 20.3 \\
\hline \multirow[t]{3}{*}{ Since 2000} & 1 & 82 & 20.7 & 23.2 & 56.1 & 28.5 \\
\hline & 2 & 60 & 18.3 & 23.3 & 58.3 & 32.6 \\
\hline & 3 & 22 & 13.6 & 22.7 & 63.6 & 67.5 \\
\hline \multicolumn{7}{|c|}{ Type of investors } \\
\hline Direct & 1 & 169 & 30.8 & 21.3 & 47.9 & 21.3 \\
\hline \multirow[t]{2}{*}{ investors } & 2 & 75 & 30.7 & 18.7 & 50.7 & 28.4 \\
\hline & 3 & 49 & 30.6 & 16.3 & 53.1 & 25.9 \\
\hline Indirect & 1 & 62 & 24.2 & 24.2 & 51.6 & 0.4 \\
\hline \multirow[t]{2}{*}{ investors } & 2 & 39 & 23.1 & 12.8 & 64.1 & 9.8 \\
\hline & 3 & 20 & 20.0 & 5.0 & 75.0 & 23.3 \\
\hline
\end{tabular}

Note. In our database, a significant proportion of observations lack data on the number of employees. In the calculations, we have used only those firms whose employment data were available for all the years of having outward FDI and during the last year of undertaking outward FDI.

As we can see, already in the first year of having outward FDI, employment in the parent was $14.6 \%$ higher than before. Although in the second and third year even extra jobs were added, we can see that most of the effect took place already during the first year of investment. That 
may be so because the auxiliary employment needed to service foreign investments needs to be employed already at the beginning of investment and to a large extent the size of the necessary employment is fixed and is affected relatively little by growth in the scale of the subsidiaries' operations. The positive home-country employment effect is also quite broad-based - about 50-60 percent of all firms increase their employment after going abroad, thus the positive average employment growth is not due to the small number of outliers with exceptionally strong job creation. In case of investments undertaken since 2000, the employment effect was clearly stronger than for earlier investments (in the first year, 21\% and 14\%, respectively). On the one hand, that can be explained by the growing share of service firms in the OFDI, as in the service sector the effect of OFDI on the parents's employment seems to be stronger in both periods (Table 8). On the other hand, the employment effect in the first and second year after implementing investment grew both in services and manufacturing. The stronger growth of employment in services can be partly explained by the smaller size of services firm before the investment ${ }^{23}$.

Table 8. Change in employment in manufacturing and services companies after implementing outward FDI, 1995-2002: breakdown by the year of making outward FDI

\begin{tabular}{|c|c|c|c|c|c|}
\hline \multirow[t]{2}{*}{$\begin{array}{l}\text { Year of outward } \\
\text { FDI }\end{array}$} & \multirow{2}{*}{$\begin{array}{l}\text { Number of } \\
\text { firms used in } \\
\text { calculations }\end{array}$} & \multicolumn{3}{|c|}{$\begin{array}{c}\text { Percentage of firms where employment after } \\
\text { implementing outward FDI has... }\end{array}$} & \multirow{2}{*}{$\begin{array}{c}\text { Change in the number } \\
\text { of employees relative } \\
\text { to initial level, } \%\end{array}$} \\
\hline & & ..decreased & .. not changed & increased & \\
\hline \multicolumn{6}{|c|}{ Manufacturing: until 1999: } \\
\hline 1 & 17 & 47.1 & 11.8 & 41.2 & 8.5 \\
\hline 2 & 14 & 57.1 & 0 & 42.9 & -11.1 \\
\hline 3 & 13 & 46.2 & 7.7 & 46.2 & -14.3 \\
\hline \multicolumn{6}{|c|}{ Manufacturing: since 2000} \\
\hline 1 & 11 & 18.2 & 9.1 & 72.7 & 10.9 \\
\hline 2 & 9 & 22.2 & 11.1 & 66.7 & 22.3 \\
\hline 3 & 4 & 0 & 0 & 100 & 120.1 \\
\hline \multicolumn{6}{|c|}{ Services: until 1999} \\
\hline 1 & 42 & 33.3 & 9.5 & 57.1 & 18.0 \\
\hline 2 & 37 & 32.4 & 13.5 & 54.1 & 28.7 \\
\hline 3 & 31 & 29 & 9.7 & 61.3 & 61.9 \\
\hline \multicolumn{6}{|c|}{ Services: since 2000} \\
\hline 1 & 67 & 16.4 & 26.9 & 56.7 & 57.9 \\
\hline 2 & 49 & 20.4 & 22.4 & 57.1 & 52.5 \\
\hline 3 & 17 & 17.6 & 29.4 & 52.9 & 39.8 \\
\hline
\end{tabular}

Note. In our database, a significant proportion of observations lack data on the number of employees. In the calculations we have used only those firms whose employment data were available for all the years of having outward FDI and during the last year of undertaking outward FDI.

\footnotetext{
${ }^{23}$ At the time of investment (the last year a firm has no foreign affiliates), the average employment size in services was 25 employees in case of direct investors, and 28 employees in case of indirect investors. In manufacturing, the respective figures were 99 and 178 (own calculations).
} 
Another result is the much stronger employment effect of direct outward FDI compared with indirect OFDI (see Table 7) ${ }^{24}$. In our opinion, that is caused by the following three factors:

1) The subsidiaries of the direct investors are served from Estonia, thus the necessary ancillary employment is created over there. In case of indirect investors, the subsidiaries are served from other locations rather than from Estonia, thus no (or fewer) extra jobs are created in Estonia.

2) Our surveys among the Estonian companies have shown that the subsidiaries of the Estonian investors have a relatively low level of autonomy, thus several functions are not transferred to subsidiaries; they need to be fulfilled in Estonia and thus require extra jobs (Männik et al. 2006).

3) The direct investors are relatively smaller at the time of investment than the indirect investors $^{25}$, so they need to create more jobs to serve the investments, while the indirect investors may have built the necessary capacity already in the past. But we would also expect, the subsequent employment growth among the direct investors to be more dependent on the initial size than among the indirect investors, as in the former case the investments are served from Estonia, in the latter, from other countries.

\section{Results of the regression analysis and propensity score match- ing}

We will next move on to presenting the results of the regression analysis. Table 9 shows the parameter estimates of the employment growth model. The interpretation is that a positive value of the outward FDI parameter indicates that Estonian firms with affiliates abroad have on average faster employment growth than firms without foreign affiliates. We note that this interpretation is different from that of the matching model, where we looked at the growth in the number of employees during the first years of being multinational vis-a-vis the previous level.

We will first take a short look at the parameters of the control variables. The results from Table 9 indicate unambiguously that employment of small firms is growing more rapidly and

\footnotetext{
${ }^{24}$ In the survey of investors, the results were different, the indirect investors had a stronger impact on the employment of the parent company (Varblane et al. 2001, pp. 37), but the difference was not statistically significant.

${ }^{25}$ We can notice that at the time of investment (the last year a firm has no foreign affiliates), the average employment size was 40 employees in the case of direct investors, and 52 employees in the case of indirect investors. However, as direct investors grow faster after the investment, the overall average size of the direct investors in our sample was 113 employees versus 83 employees for indirect investors.
} 
that of old firms more slowly. That is a common finding in the literature on the determinants of firm-level employment growth. The negative relationship may emerge, for example, because in the conditions of uncertainty concerning a firm's post-entry performance and some investments being sunk costs, a rational strategy would be to start as small and grow over time if positive information on profitability is revealed from past earnings. Labour cost (wages including payroll taxes), as expected, has a negative and statistically significant effect on employment growth (since wage growth is expected to inhibit labour demand). Both labour productivity and capital intensity, as expected, have a positive impact on the employment growth. Such a result is not surprising, given the previous empirical evidence on the reallocation process in Estonia: more productive firms are able to increase their market share, and thus increase their employment at the expense of less productive firms.

Being an exporter also means up to $4 \%$ faster employment growth. That is reasonable, given that the growth prospects of domestic market oriented firms are limited due to the relatively small size of the Estonian market. We have some concerns about the rather low goodness-offit of the regressions (4\%); however, in earlier studies on firm-level growth the goodness-offit has been on similarly low levels ${ }^{26}$.

We will now move on to our core set of parameters. The estimation results support the research proposition about the positive home country employment effect of OFDI from Estonia (the dummy for firms with foreign affiliates is always positive and significant). Given the other determinants of firm growth, firms with outward investments experienced about 3\% faster growth of employment in case of investments made until 1999; the investments made from 2000 onwards were more successful in this respect, as firms with such affiliates grew 6 $\%$ faster than the other firms. That re-confirms the differences between two periods detected by the descriptive tables. Besides being statistically significant, the effect is also nonnegligible.

\footnotetext{
${ }^{26}$ For instance, in Heshmati (2001) the adjusted $\mathrm{R}^{2}$ was in the range of $8.5-19.8 \%$, in Konings et al. (2002) $4.7 \%$.
} 
Table 9. Employment growth model parameter estimates: robust regression

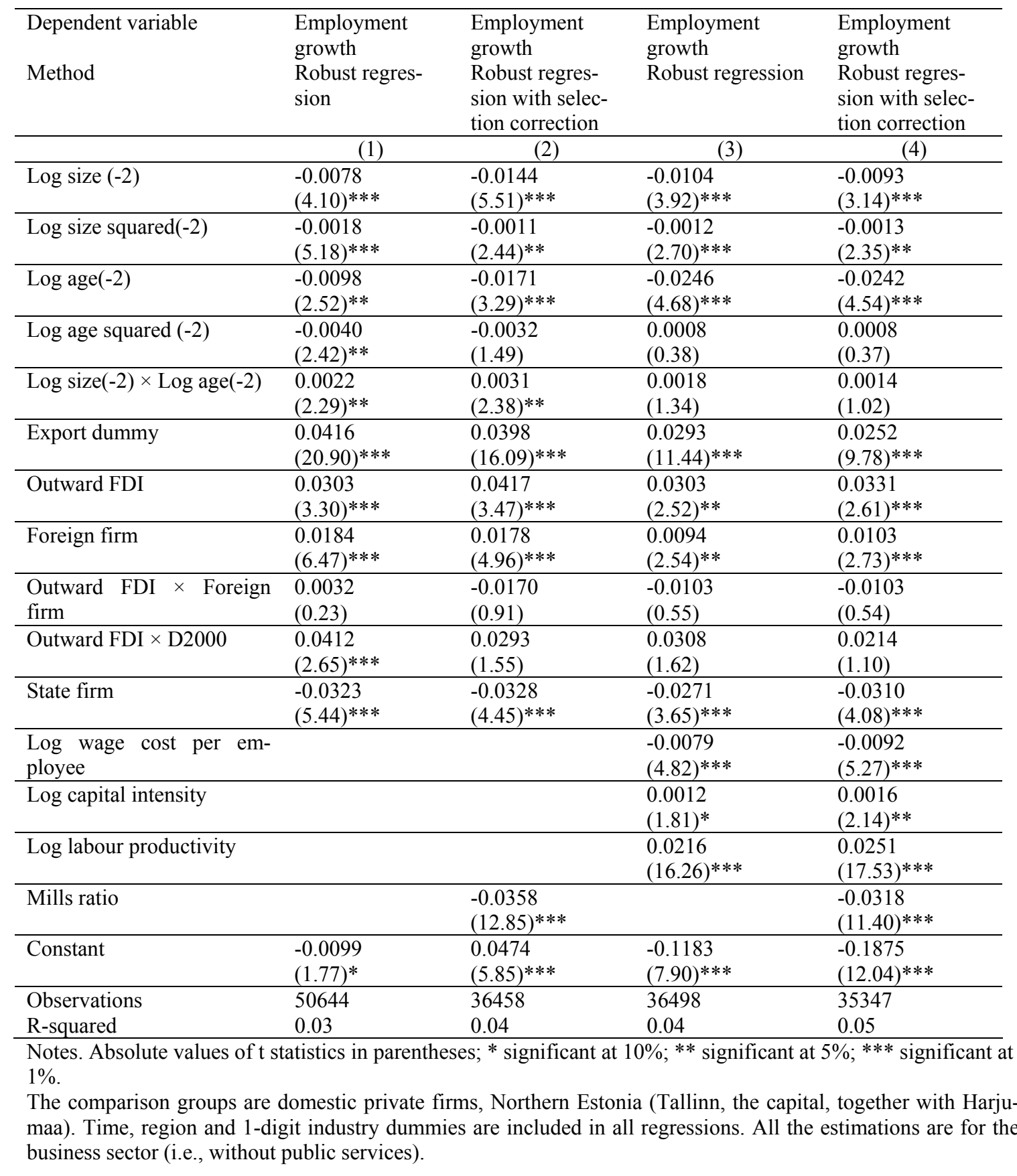

However, no significant differences could be observed between direct and indirect investors (those being owned by Estonian and foreign capital, respectively). The interaction effect (measured by the variable Outward FDI $\times$ Foreign Firm) has a negative sign, but is not significant. The reason why that difference appeared in descriptive tables but not in regressions might be that in regression we control for factors like firm size: indirect investors are generally larger than direct investors, so at least some (or perhaps even most) of the faster growth 
of the direct investors vis-a-vis indirect investors can be attributed to their smaller size. Another source of difference might be that foreign firms pay higher wages than domestic firms (as we could see, the level of labour costs affected net employment creation negatively). The effect of inward FDI on employment growth is positive and significant as well (as was noted already by Masso et al. 2006), i.e., foreign-owned firms create jobs at a higher speed than domestic firms ${ }^{27}$. That effect has appeared also in earlier studies on firm growth in transition economies (see Faggio and Konings 2003).

As we can see, the results are qualitatively similar from the two regressions with and without adjustment for selection due to exit. Mill's ratio calculated from the probit model for firms' survival turned out to be statistically significant in the employment growth equation and its inclusion had a significant effect on the size of some coefficients of exogenous variables. That indicates that the selection bias due to a firm's exit needs to be controlled for, as the employment growth patterns in the final sample differ systematically from these firms that are excluded due to exits. However, neither the coefficients of outward FDI nor the inward FDI dummies changed considerably.

Next let us move on to the presentation and discussion of the results of propensity score matching. The results of probit estimation - used in calculating the conditional probability of investing abroad - are presented in Table 10, where the dependent variable (NEWOFDI) is the dummy variable indicating whether the firm has invested abroad for the first time. Note that this variable is thus different from the outward FDI dummy used in the regression analy$\operatorname{sis}^{28}$. There the outward FDI dummy indicated all firms that had outward FDI, including those that were multinationals during the whole period studied.

Following the suggestions in Sianesi (2002) and Caliendo and Kopeinig (2005), we include the exogenous variables that determine the FDI decision, as of one period before the new outward FDI. In this way, these variables will be independent of later outward FDI. As outward

\footnotetext{
${ }^{27}$ The interpretation of the coefficients for the ownership dummies is as follows. The dummy for "Foreign firms" indicates how much is the employment growth for firms with foreign owners but without foreign affiliates higher or lower than that for domestic firms (our reference group). The dummy for outward FDI shows the impact on employment growth of foreign investment in case of direct investors (firms with Estonian owners). The effect of indirect OFDI can be viewed as a sum of coefficients of Outward FDI and the interaction term "Outward FDI*Foreign firm".

28 In particular, NEWOFDI $I_{i, t}=1$ if OUTFDI $_{i, t-1}=0$ and $O U T F D I_{i, t}=1$, otherwise $N E W O F D I_{i, t}=0$.
} 
FDI at the beginning of the period is different from the end-of-period outward $\mathrm{FDI}^{29}$, we will study these separately for periods 1996-1999 and 2000-2002 (for both periods we estimated the propensity score, did the balancing property test and estimated the ATT).

Table 10 Probit model for making new outward FDI

\begin{tabular}{|c|c|c|c|c|}
\hline & \multicolumn{2}{|c|}{ Services } & \multicolumn{2}{|c|}{ Manufacturing } \\
\hline Variables: & 1996-1999 & $2000-2002$ & 1996-1999 & $2000-2002$ \\
\hline Size (-1) & $\begin{array}{l}0.388 \\
(0.057) * * *\end{array}$ & $\begin{array}{l}0.217 \\
(0.043) * * *\end{array}$ & $\begin{array}{l}0.476 \\
(0.116)^{* * *}\end{array}$ & $\begin{array}{l}0.281 \\
(0.088)^{* *}\end{array}$ \\
\hline Log age & $\begin{array}{l}0.068 \\
(0.037)^{*}\end{array}$ & $\begin{array}{l}0.008 \\
(0.018)\end{array}$ & $\begin{array}{l}0.032 \\
(0.074)\end{array}$ & $\begin{array}{l}-0.014 \\
(0.039)\end{array}$ \\
\hline Log labour productivity $(-1)$ & $\begin{array}{l}0.643 \\
(0.120)^{* * *}\end{array}$ & $\begin{array}{l}0.386 \\
(0.096) * * *\end{array}$ & $\begin{array}{l}1.016 \\
(0.292)^{* * *}\end{array}$ & $\begin{array}{l}0.111 \\
(0.193) \\
\end{array}$ \\
\hline Foreign firm $(-1)$ & $\begin{array}{l}-0.013 \\
(0.186) \\
\end{array}$ & $\begin{array}{l}0.029 \\
(0.121) \\
\end{array}$ & $\begin{array}{l}-0.196 \\
(0.305) \\
\end{array}$ & $\begin{array}{l}-0.638 \\
(0.311)^{* *}\end{array}$ \\
\hline Export dummy (-1) & $\begin{array}{l}0.154 \\
(0.155)\end{array}$ & $\begin{array}{l}0.258 \\
(0.112)^{* *}\end{array}$ & & $\begin{array}{l}0.431 \\
(0.332)\end{array}$ \\
\hline Log capital intensity $(-1)$ & $\begin{array}{l}-0.041 \\
(0.055) \\
\end{array}$ & $\begin{array}{l}0.054 \\
(0.036)\end{array}$ & $\begin{array}{l}-0.066 \\
(0.115) \\
\end{array}$ & $\begin{array}{l}0.180 \\
(0.094)^{*}\end{array}$ \\
\hline Log labour cost per employee $(-1)$ & $\begin{array}{l}-0.277 \\
(0.105)^{* * *}\end{array}$ & $\begin{array}{l}0.064 \\
(0.092) \\
\end{array}$ & $\begin{array}{l}-0.148 \\
(0.333) \\
\end{array}$ & $\begin{array}{l}0.107 \\
(0.231) \\
\end{array}$ \\
\hline Equity/Assets (-1) & $\begin{array}{l}0.1 \\
(0.25)\end{array}$ & $\begin{array}{l}0.017 \\
(0.143)\end{array}$ & $\begin{array}{l}-0.215 \\
(0.263)\end{array}$ & $\begin{array}{l}-0.29 \\
(0.216)\end{array}$ \\
\hline Profit/Sales (-1) & $\begin{array}{l}-0.906 \\
(0.375)^{* *}\end{array}$ & $\begin{array}{l}-0.668 \\
(0.222) * * *\end{array}$ & $\begin{array}{l}-1.476 \\
(0.788)^{*}\end{array}$ & $\begin{array}{l}-0.056 \\
(0.067)\end{array}$ \\
\hline Constant & $\begin{array}{l}-142.61 \\
(73.756)^{*}\end{array}$ & $\begin{array}{l}-25.188 \\
(36.914)\end{array}$ & $\begin{array}{l}-77.438 \\
(148.229) \\
\end{array}$ & $\begin{array}{l}20.461 \\
(78.338)\end{array}$ \\
\hline Sector dummies & Yes & Yes & Yes & Yes \\
\hline Region dummies & Yes & Yes & Yes & Yes \\
\hline Year dummies & Yes & Yes & Yes & Yes \\
\hline Observations & 11593 & 22072 & 1979 & 5516 \\
\hline Pseudo R-squared & 0.228 & 0.21 & 0.3113 & 0.198 \\
\hline LR chi2 & 124.09 & 203.12 & 54.9 & 45.67 \\
\hline
\end{tabular}

Note: standard errors are in parentheses; * significant at $10 \%$; ** significant at $5 \% ; * * *$ significant at $1 \%$. Exogenous variables are lagged by one period. Lagged export dummy was dropped in the probit model by the psmatch2.ado program for the manufacturing industry in the period 1996-1999.

We used the following pre-OFDI characteristics of firms to predict the probability of engaging in investment abroad: a firm's size, labour productivity (value added per employee), age, indicator variable of foreign ownership, export dummy, capital intensity, wage per employee, profit to sales ratio (a proxy of the Lerner index), debt to equity ratio, sector dummies (at 2digit NACE level), region dummies, and year dummies. The choice of variables is quite similar to other studies doing a similar analysis based on other countries (see e.g., Barba Navaretti and Castellani 2004).

\footnotetext{
${ }^{29}$ For instance, the macroeconomic conditions in Estonia changed in the course of time as did the motives for undertaking foreign investment: in the more recent years, moving production into locations with more favourable input costs might have become a more important reason for undertaking foreign investment due to the high speed of wage growth.
} 
The estimation results show quite plausible signs for the right-hand-side variables, although many of the variables are not significant in the case of the manufacturing industry, and the results also show some differences between periods. As the aim of the probit models is to calculate the propensity score of doing outward FDI and not to study in detail the determinants of outward FDI, we will not concentrate on discussing the sign and significance of each exogenous variable. Note, however, that the probability of making FDI is generally larger for firms with higher labour productivity (just like the implication of the model by Helpman et al. 2004). After accounting for several other control variables, including productivity, the inward FDI is not any more an important determinant of the outward FDI decision (except 2000-2002 in the manufacturing sector $)^{30}$. This is probably due to high correlation between the inward FDI and the productivity variable.

Before calculating the ATT effect, we checked whether the matching based on the propensity score, estimated in the probit models above, was successful: that is, whether the treatment and control group observation had similar characteristics now. This was done on the basis of a standard t-test. The mean values of variables determining the selection into treatment in the probit models above were compared between outward FDI firms and non-outward FDI firms/control group before matching and after matching. After matching, these differences in a period before treatment should be not significant if the matching is successful - which was also the case (the test results for the services sector in 2000-2002 can be found in Appendix 3, and for the other sectors and periods are available on request from the authors).

As the next step, the ATT of making outward FDI is found, with a change in the log of employment at the period of investment $t$ as the outcome variable. We tried 3 different outcome variables - these were the employment growth rates over the 1,2 and 3 first years of outward investment. This post-investment employment growth was compared between the treatment and control group, using the nearest neighbour matching with 2 or 5 neighbours, or Kernel matching (with bandwidth of the size 0.06). The results are shown separately for the services sector in Table 11 and for the manufacturing sector in Table 12. First, in services the estimated treatment effect is always positive and in a number cases statistically significant. Con-

\footnotetext{
${ }^{30}$ In principle, in order to evaluate the significance of individual variables in the probit model it would be preferable to use the standard errors corrected for heteroscedasticity. However, that is not so important in this context given that our interest is in calculating the propensity score.
} 
cerning the first year of investment, the effect is stronger in the second period (2000-2002); in that case the estimates lie within the range of 11-15 percentage points - that is undoubtedly an economically significant effect. The effect is larger than what we found in the employment growth regressions. In manufacturing, ATT is positive and significant only in the second period (2000-2002), and for the second and third year of investment. Thus, in the first year of investment, the effect is stronger in services, while in the second year of investment it is stronger in manufacturing. A possible explanation is as follows. In manufacturing, in the short run, relocation abroad might decrease home employment if the activities previously conducted at home are relocated abroad. In the long run, the positive effect on employment may show up due to the increased competitiveness of the investor, complementarity between the firm's foreign and home operations (see discussions in Section 2). The bigger number of treatment observations in the services sector enables detection of statistically significant results there more frequently. Thus, although not all estimations have resulted in statistically significant results, at least in the services sector the difference between the treatment group and the control group (the ATT effect) was always positive. Hence, we can argue that the effects are at least not negative in that sector and the outward FDI do not cause job loss at home.

Table 11. Effect of outward FDI on employment growth at home (ATT): propensity score matching results for the service sector

\begin{tabular}{lllccccc}
\hline Period & \multicolumn{1}{c}{$\begin{array}{c}\text { Matching } \\
\text { method }\end{array}$} & \multicolumn{2}{c}{ ATT 1-year } & \multicolumn{2}{c}{ ATT 2-years } & \multicolumn{2}{c}{ ATT 3-years } \\
\cline { 2 - 8 } & & Difference & T-stat. & Difference & T-stat. & Difference & T-stat. \\
\hline 1996-1999 & Unmatched & 0.132 & $2.16^{* *}$ & 0.012 & 1.940 & 0.231 & $2.11^{* *}$ \\
\cline { 2 - 8 } & NN 5 & 0.036 & 0.430 & 0.049 & 1.810 & 0.074 & 0.620 \\
\cline { 2 - 8 } & NN 2 & 0.048 & 0.470 & 0.094 & 1.070 & 0.174 & 1.290 \\
\cline { 2 - 8 } & Kernel & 0.119 & 1.570 & 0.149 & $2.31^{* *}$ & 0.218 & $2.00^{* *}$ \\
\hline 2000-2002 & Unmatched & 0.150 & $3.39^{* * *}$ & 1.670 & 1.070 & 0.109 & 1.460 \\
\cline { 2 - 8 } & NN 5 & 0.110 & $1.67^{*}$ & 0.078 & 1.210 & 0.094 & 1.040 \\
\cline { 2 - 8 } & NN 2 & 0.134 & $1.92^{*}$ & 0.121 & 1.590 & 0.089 & 0.880 \\
\cline { 2 - 8 } & Kernel & 0.148 & $2.37^{* *}$ & 0.064 & 0.057 & 0.107 & 1.260 \\
\hline
\end{tabular}

Note: * significant at 10\%; ** significant at \%;*** significant at $1 \%$. NN -5 : nearest neighbour matching with 5 matches; NN - 2: nearest neighbour matching with 2 matches; ATT - Average Treatment Effect on the Treated (ATT), t-statistics are in parentheses. In case of Kernel matching, the Epanechnikov kernel has been used, the bandwidth has been set at 0.06 (the default value in psmatch2 program).

Concerning different matching algorithms, Kernel matching produces statistically significant results more often than the nearest neighbour matching, as the mean employment change of the counterfactuals is much lower in case of Kernel matching. We can also note that the ATT 
estimated with Kernel matching is much closer to the unmatched case than the ATT estimated with the nearest neighbour matching. The reason is that in case of Kernel matching all the observations in the control group are used to construct the counterfactual, with more similar observations given higher weights, while in case of nearest neighbour matching only a small number of observations is used (Caliendo and Kopeinig 2005).

Table 12. Effect of outward FDI on employment growth at home (ATT): propensity score matching for the manufacturing sector

\begin{tabular}{lllccccc}
\hline Period & \multicolumn{1}{c}{$\begin{array}{c}\text { Matching } \\
\text { method }\end{array}$} & \multicolumn{2}{c}{ ATT 1-year } & \multicolumn{2}{c}{ ATT 2-years } & \multicolumn{2}{c}{ ATT 3-years } \\
\cline { 3 - 8 } & & Difference & T-stat. & Difference & T-stat. & Difference & T-stat. \\
\hline 1996-1999 & Unmatched & -0.041 & -0.360 & -0.057 & -0.390 & -0.107 & -0.620 \\
\cline { 2 - 8 } & NN 5 & 0.060 & 0.630 & -0.207 & -1.400 & -0.236 & -1.310 \\
\cline { 2 - 8 } & NN 2 & 0.092 & 0.690 & -0.850 & -0.850 & -0.309 & -1.320 \\
\cline { 2 - 8 } & Kernel & -0.044 & -0.570 & -0.061 & -0.540 & -0.106 & -0.690 \\
\hline 2000-2002 & Unmatched & 0.101 & 1.000 & 0.144 & 1.020 & 0.448 & $2.63^{* * *}$ \\
\cline { 2 - 7 } & NN 5 & 0.031 & 0.380 & 0.206 & $1.84^{*}$ & 0.447 & $2.54^{* * *}$ \\
\cline { 2 - 8 } & NN 2 & -0.058 & -0.410 & 0.282 & 1.450 & 0.394 & $2.03^{* *}$ \\
\cline { 2 - 8 } & Kernel & 0.101 & $1.79 *$ & 0.144 & $1.74 *$ & 0.447 & $2.67^{* * * *}$ \\
\hline
\end{tabular}

Note: * significant at $10 \% ; * *$ significant at $\% ; * * *$ significant at $1 \%$. NN -5 : nearest neighbour matching with 5 matches; NN - 2: nearest neighbour matching with 2 matches; ATT - Average Treatment Effect on the Treated (ATT), t-statistics are in parentheses.

An issue that we noticed while doing the matching based on the panel data was that, although the probit model included the year dummies, the matches between the treatment group and the control group were sometimes from different years. Although this might not be a big problem, as we have divided the whole period into two parts that in terms of economic development are more similar, a robustness check might still be useful. In Table 13 below, year-by-year matching is performed on the basis of the service sector ${ }^{31}$ and the ATT effects are presented separately for each year. The years 1996 and 1997 were omitted from here because the number of new outward investors in these years was very low. The estimated ATTs were positive for all years (except 2002) although in most cases statistically significant; the latter result was expected, given the rather small number of new investors in each distinct year.

\footnotetext{
${ }^{31}$ The number of treatment observations in each single year is too small in the manufacturing industry to enable year-by-year matching.
} 
Table 13. Year-by-year matching for the service sector: the first year of outward FDI

\begin{tabular}{cccc}
\hline Year & NN 5 matching & NN 2 matching & Kernel matching \\
\hline 1998 & 0.069 & 0.056 & 0.171 \\
& $(0.920)$ & $(0.610)$ & $\left(2.390^{* *}\right)$ \\
\hline 1999 & 0.140 & 0.158 & 0.088 \\
& $(0.730)$ & $(0.790)$ & $(0.470)$ \\
\hline 2000 & 0.182 & 0.179 & 0.179 \\
& $(1.250)$ & $(1.210)$ & $(1.290)$ \\
\hline 2001 & 0.253 & 0.168 & 0.219 \\
& $(1.750 *)$ & $(1.100)$ & $(1.650)$ \\
\hline 2002 & -0.008 & 0.069 & -0.025 \\
& $(-0.140)$ & $(1.520)$ & $(-0.650)$ \\
\hline
\end{tabular}

Note: * significant at $10 \% ; * *$ significant at $\% ; * * *$ significant at $1 \%$. NN -5 : nearest neighbour matching with 5 matches; NN - 2: nearest neighbour matching with 2 matches; ATT - Average Treatment Effect on the Treated (ATT), t-statistics are in parentheses.

Additionally, the ATT effect was calculated separately for indirect and direct investors in the service sector in the period 2000-2002 (Table 14). The effect was stronger for direct investors (e.g., in case of Kernel matching in the first year of investment by 4.5 percentage points), and also more often statistically significant. That confirms our second proposition. Due to the small number of observations, the effect of indirect OFDI was not calculated for the manufacturing sector. The results for the second and third year of investment are insignificant; the shortness of the sample period being the cause why we can observe outward investors only for a short period after the investment.

Table 14. Matching results for indirect and direct investors: the service sector, 20002002

\begin{tabular}{lllccccc}
\hline \multirow{2}{*}{$\begin{array}{l}\text { Type of inves- } \\
\text { tors }\end{array}$} & \multirow{2}{*}{ Method } & \multicolumn{2}{c}{ ATT 1-year } & \multicolumn{2}{c}{ ATT 2-years } & \multicolumn{2}{c}{ ATT 3-years } \\
\cline { 2 - 8 } Indirect & & Difference & T-stat. & Difference & T-stat. & Difference & T-stat. \\
\cline { 2 - 8 } & Unmatched & 0.111 & 1.44 & 0.108 & 0.98 & 0.071 & 0.53 \\
\cline { 2 - 8 } & NN 5 & 0.030 & 0.52 & 0.034 & 0.36 & 0.004 & 0.02 \\
\cline { 2 - 8 } & NN 2 & 0.111 & 0.77 & 0.021 & 0.19 & 0.045 & 0.21 \\
\cline { 2 - 8 } & Kernel & 0.105 & $2.14^{* *}$ & 0.100 & 1.17 & 0.061 & 0.30 \\
\hline Direct & Unmatched & 0.167 & $3.11^{* * *}$ & 0.045 & 0.61 & 0.121 & 1.32 \\
\cline { 2 - 8 } & NN 5 & 0.184 & $1.95^{*}$ & -0.036 & -0.4 & 0.132 & 1.31 \\
\cline { 2 - 8 } & NN 2 & 0.142 & 1.32 & 0.010 & 0.12 & 0.180 & 1.49 \\
\cline { 2 - 8 } & Kernel & 0.156 & $1.75^{*}$ & 0.045 & 0.61 & 0.118 & 1.37 \\
\hline
\end{tabular}

Notes: NN - 5: nearest neighbour matching with 5 matches; $N N-2$ : nearest neighbour matching with 2 matches; ATT - Average Treatment Effect on the Treated (ATT). 


\section{Conclusions and implications}

Traditional literature on relocation has heavily analysed the employment effect in the case of investments in the manufacturing sector from high-production-cost home countries to lowcost host countries. The contribution of the current paper is an analysis of the home country employment effect of outward foreign direct investments from Estonia as a low-cost transition economy. We used regression analyses and propensity score matching on the firm level panel data about the whole population of Estonian firms between 1995 and 2002.

The results of the employment growth regression analysis indicated that in general outward FDI was positively related to home country employment growth. This supported our research proposition and could be explained by the prevailing horizontal South-South type of outward foreign direct investments from Estonia, by which market seeking aspect, intention to reap benefits of economies of scale and customers following motives played a dominant role. The horizontal FDI in neighbouring catching up economies helps to increase the market share in the host country and allow using the economies of scale effect, which supports home employment growth. The fear of outward FDI moving jobs to other locations is often found among policymakers in the home countries of investors. Our results show that there is no firm ground for such fears in the case of low-cost transition countries and that outward FDI had a positive short-term effect association with employment.

Our results also suggest differences between the home country employment effect for direct and indirect outward foreign direct investments. For indirect investors - foreign-owned firms, which had invested abroad through their subsidiaries in Estonia - employment growth was on average even higher than for direct investors. This is explained by the following factors. First, subsidiaries of direct investors are served from other locations than Estonia, and no extra jobs are needed in Estonia. Second, due to the low level of autonomy of the subsidiaries of the Estonian investors, relatively many jobs are required in Estonia to fulfil the business functions not transferred to subsidiaries. Third, direct investors are much smaller at the time of investment than indirect investors, thus they need to create more jobs to serve the investments. However, the effect was positive also in case of indirect investors. Thus, though in the literature it has been found that low-wage countries could be employment substitutes for one another, that seems not to be the case with multinational's investments in Estonia. 
The effect was found to be stronger in the services sector than in manufacturing. We argued that this is explained by the non-tradability of services and the smaller size of the domestic service firms investing abroad, which means that outward investments could require additional jobs at home in order to manage the process of increasing the complexity of service provision. Both in manufacturing and services the effect was found to be much stronger for investments started after 1999, which is connected to the improved macro-economic performance of Estonia (particularly faster rate of economic growth) since 2000.

Our results so far indicate a possible positive relationship between outward FDI and employment growth at home in Estonia and that the effects are likely to be significantly different in different time periods, types of investors and economic sectors. However, not all results were completely robust. One caveat of this analysis is that different matching algorithms sometimes gave somewhat different ATT effects. Thus for future analysis and robustness checks, the application of other approaches, like the instrumental variable approach/system GMM, may be useful.

The relevance of the topic is growing rapidly as long as the stock of OFDI from new EU member states grows. Clearly, the employment effect of OFDI from new EU member states could be country-specific. Therefore it could be interesting to observe the difference between the employment effects in relatively high-income countries with Estonia as a relatively lowincome country.

The results of our study imply for economic policy that there is no ground for fears about job losses at home when firms in low-cost countries establish affiliates in other countries. On the contrary, especially in the case of investments by domestically owned firms quite strong job creation is expected at home after investment. Given that, the policy should rather promote the entry of domestic firms into other markets via direct investments. In earlier surveys, the investors have indicated a number of steps the home country government can take to facilitate outward investments, such as providing information and contacts about target markets (Varblane et al. 2001). As regards the CEE countries, at least some problems have been solved thanks to the eastern enlargement of the EU (concerning the target countries that belong to the EU). Still, there might be some problems present that inhibit investment abroad, and therefore one may consider the need for a governmental strategy for foreign expansion of domestic companies. 


\section{References}

Abraham, F. and J. Konings (1999), "Does the Opening of Central and Eastern Europe Kill Jobs in the West?'”, World Economy, Vol. 22, pp. 585-603.

Altzinger, W. and C. Bellak (1999), "Direct Versus Indirect FDI: Impact On Domestic Exports And Employment", Vienna University of Economics and Business Administration Working Papers Series: Growth and Employment in Europe: Sustainability and Competitiveness, Working Paper No. 9.

Amiti, M. and S. J. Wei (2005), "Fear of service outsourcing: is it justified?“, Economic Policy, Vol. 20, Issue 42, pp. 308-347.

Arnold, J. M. and B. Smarzynska Javorcik (2005), “Gifted Kids or Pushy Parents? Foreign Acquisitions and Plant Performance in Indonesia”, CEPR Discussion Paper No. 5065.

Barba Navaretti, G. and D. Castellani (2004), "Investment Abroad and Performance at Home: Evidence from Italian Multinationals”, CEPR Discussion Paper No. 4284.

Barba Navaretti, G., Castellani, D. and A.-C. Disdier (2006), "How Does Investing in Cheap Labour Countries Affect Performance at Home? France and Italy", CEPR Discussion Paper No. 5765 .

Blomström, M, Fors, G. and R. E. Lipsey (1997), "Foreign Direct Investment and Employment: Home Country Experience in the United States and Sweden", NBER Working Paper No. 6205 .

Blomström, M., Fors, G. and R.E. Lipsey (1997), "Foreign Direct Investment and Employment: Home Country Experience in the United States and Sweden”, Economic Journal, Vol. 107, pp. 1987-1997.

Braconier, H. and K. Ekholm (1999), "Swedish Multinationals and Competition from High and Low-Wage Countries", CEPR Discussion Paper No. 2323.

Braconier, H. and K. Ekholm (2000), "Swedish Multinationals and Competition from High and Low-Wage Countries", Review of International Economics, Vol. 8, Issue 3, pp. 448-461.

Braconier, H. and K. Ekholm (2001), "Foreign Direct Investment in Central and Eastern Europe: Employment Effects in the EU”, CEPR Working Paper No. 3052.

Brainard, S. L. and D. Riker (1997), “Are U.S. Multinationals Exporting U.S. Jobs?”, NBER Working Paper No. 5958. 
Braunerhjelm, P. and L. Oxelheim (2000), “Does Foreign Direct Investment Replace Home Country Investment? The Effect of European Integration on the Location of Swedish Investment', Journal of Common Market Studies, Vol. 38, Issue 2, pp. 199-221.

Braunerhjelm, P., Oxelheim, L. and P. Thulin (2005), "The Relationship between Domestic and Outward Foreign Investment Revisited: The Impact of Industry-Specific Effects", Royal Institute of Technology, Stockholm, CESIS Electronic Working Paper No. 35.

Bruno, G. and A.M. Falzoni (2000), "Multinational Corporations, Wages and Employment: Do Adjustment Costs Matter?", CEPR Working Paper No. 2471.

Caliendo, M. and S. Kopeinig. (2005), "Some Practical Guidance for the Implementation of Propensity Score Matching”, IZA Discussion Paper No. 1588.

Cuyvers, L., Dumont, M., Rayp, G. and K. Stevens (2005), "Home Employment Effects of EU Firms' Activities in Central and Eastern European Countries", Open Economies Review, Vol. 16, Number 2, pp. 153-174.

Dewit, G., Görg, H. and C. Montagna (2004), "Should I stay or should I go? A Note on Employment Protection, Domestic Anchorage, and FDI”, IZA Discussion Paper No. 845.

Ekholm, K. and J. Markusen (2002), "Foreign Direct Investment and EU - CEE Integration”, background paper for the conference "Danish and International Economic Policy", University of Copenhagen Copenhagen, May 23-24 2002.

Evans, D. S. (1987), “The Relationship between Firm Growth, Size and Age: Estimates for 100 Manufacturing Industries”, Journal of Industrial Economics, Vol. 35, pp. 567-581.

Faggio, G. and J. Konings (2003), "Job creation, job destruction and employment growth in transition countries in the 90s", Economic Systems, Vol. 27, pp. 129-154.

Feenstra, R. C. and G. H. Hanson (1996), “Globalization, Outsourcing, and Wage Inequality”, American Economic Review, Vol. 86, pp. 240-245

Hansson, P. (2005), "Skill Upgrading and Production Transfer within Swedish Multinationals in the 1990s", Scaninavian Journal of Economics, Vol. 107, Issue 4, pp. 673-692.

Helpman, E., Melitz, M. J. and S. R. Yeaple (2004), "Export versus FDI with Heterogeneous Firms", The American Economic Review, Vol. 94, Issue 1, pp. 300-316.

Heshmati, A. (2001), "On the Growth of Micro and Small Firms: Evidence from Sweden", Small Business Economics, Vol. 17, pp. 213-228. 
Huttunen, K. (2005), “The Effect of Foreign Acquisition on Employment and Wages: Evidence from Finnish Establishments”, HECER Discussion Paper No. 62.

Jovanovic, B. (1982), "Selection and the Evolution of an Industry", Econometrica, Vol. 50, Issue 3, pp. 649-670.

Kokko, A. (2006), “The Home Country Effects of FDI in Developed Economies”, The European Institute of Japanese Studies, EIJS Working Paper No. 225.

Konings, J. (2003), “Are Wage Cost Differentials Driving Delocalisation?”, LICOS Centre for Transition Economics Disscussion Paper No. 134.

Konings, J. and A. Murphy (2001), "Do Multinational Enterprises Substitute Parent Jobs for Foreign Ones? Evidence from European Firm-Level Panel Data”, CEPR Discussion Paper No. 2972.

Konings, J. and A. Murphy (2003), "Do Multinational Enterprises Relocate Employment to Low Wage Regions? Evidence from European Multinationals”, LICOS Centre for Transition Economics Disscussion Paper No. 131.

Konings, J., Kupets, O. and H. Lehmann (2002), "Gross Job Flows in Ukraine: Size, Ownership and Trade Effects", IZA Discussion Paper No. 675.

Kravis, I. and R. E. Lipsey (1988), “The Effect of Multinational Firms' Foreign Operations on Their Domestic Employment”, NBER Working Paper No. 2760.

Lankes, H.-P. and A. J. Venables (1996), "FDI in Economic Transition: The Changing Pattern of Investment”, Economics of Transition, Vol. 4, Issue 2, pp. 331-347.

Leuven, E. and B. Sianesi. (2003), "PSMATCH2: Stata module to perform Mahalanobis and propensity score matching, common support graphing, and covariate testing". http://ideas.repec.org/c/boc/bocode/s432001.html. Version 1.2.3.

Lipsey, R.E., E. Ramstetter and M. Blomström (2000), “Outward FDI and Parent Exports and Employment: Japan, the United States and Sweden”, Global Economy Quarterly, Vol. 1, pp. 285-302.

Lopez-de-Silanes, F., Markusen, J. R. and T. Rutherford (1996), “Trade Policy Subtleties with Multinational Firms', European Economic Review, Vol. 40, Issue 8, pp. 1605-1627. 
Männik, K., Hannula, H. and Varblane, U. (2006).’Foreign subsidiary autonomy and performance in five central and East European countries", in Helena Hannula, Slavo Radosevic and Nick von Tunzelmann (Eds.), Estonia, the New EU Economy: Building a Baltic Miracle? London: Ashgate, pp. 258-284

Mariotti, S., Mutinelli, M. And L. Piscitello (2003), Cambridge Journal of Economics, Vol. 27, pp. 419-431.

Markusen, J.R. (2002) Multinational firms and the theory of international trade. Cambridge, MA: MIT Press.

Masso, J., Eamets, R. and K. Philips, (2006), "Job Creation and Job Destruction in Estonia: Labour Reallocation and Structural Changes", in Helena Hannula, Slavo Radosevic and Nick von Tunzelmann (Eds.), Estonia, the New EU Economy: Building a Baltic Miracle? London: Ashgate, pp. 105-142.

Pellenbarg, P.H., van Wissen, L.J.G. and J. van Dijk (2001), "Firm relocation: state of the art and research prospects", University of Groningen, Research Institute SOM (Systems, Organisations and Management) Research Report No. 02D31.

Pennings, E. and L. Sleuwaegen (2000), "International relocation: firm and industry determinants", Economics Letters, Vol. 67, pp. 179-186.

Radosevic, S., Varblane, U. and T. Mickiewicz (2003), "Foreign direct investment and its effect on employment in Central Europe”, Transnational Corporations, Vol. 12, Issue 1, pp. $53-90$.

Rosenbaum, P. and D. Rubin (1983), "The Central Role of the Propensity Score in Observational Studies for Causal Effects”, Biometrika, Vol. 70, pp. 41-50.

Sachs, J. and H. Shatz (1994), “Trade and Jobs in U.S. Manufacturing”, Brookings Papers on Economic Activity, Vol. 1994, Issue 1, pp. 1-69.

Sianesi, B. (2004), “An Evaluation of the Active Labour Market Programmes in Sweden", The Review of Economics and Statistics, Vol. 86, Issue 1, 133-155.

Slaughter, M. (2000), "Production transfer within multinational enterprises and American wages", Journal of International Economics, Vol. 50, pp.449-472.

Slaughter, M.J. (1995), "Multinational Corporations, Outsourcing, and American Wage Divergence", NBER Working Paper No. 5253. 
Smarzynska Javorcik, B. (2004), "Does Foreign Direct Investment Increase the Productivity of Domestic Firms? In Search of Spillovers through Backward Linkages," The American Economic Review, Vol. 94, No. 3, pp. 605-27.

StatCorp (2003). Stata Statistical Software: Release 8.0. College Station, TX: Stata Corporation

Svetlicic, M. and A. Jaklic (2003), "Outward FDI by transition economies: basic features, trends and development implications", in Marjan Svetlicic and Matija Rojec (Eds.), Facilitating Transition by Internationalization, Ashgate, pp. 49-78.

UNCTAD (2007) Foreign Direct Investment database

[http://www.unctad.org/Templates/Page.asp?intItemID=1923\&lang=1]

Vahter P. and J. Masso (2005), “Home Versus Host Country Effects of FDI: Searching for New Evidence of Productivity Spillovers”, Bank of Estonia Working Paper No. 13.

Varblane, U., Reiljan, E. and T. Roolaht (2003), "The Role of Outward Foreign Direct Investments in the Internationalization of Estonian Firms", in Marjan Svetlicic and Matija Rojec (Eds.), Facilitating Transition by Internationalization, Ashgate, pp. 133-154.

Varblane, U., Roolaht, T., Reiljan, E. and R. Jüriado (2001), “Estonian outward foreign direct investments", University of Tartu, Faculty of Economics and Business Administration Working Paper No. 9.

World Investment Report (2005), Transnational Corporations and the Internationalization of R\&D. United Nations, New York and Geneva. 
Appendix 1. Overview of selected studies on the home country employment effects of FDI

\begin{tabular}{|c|c|c|c|c|c|}
\hline Author(s) & $\begin{array}{l}\text { Dependent } \\
\text { variable }\end{array}$ & $\begin{array}{l}\text { Data (Home coun- } \\
\text { try, period, sector) }\end{array}$ & $\begin{array}{l}\text { No of treatment } \\
\text { observations/ } \\
\text { sample size }\end{array}$ & Methods & Main results \\
\hline $\begin{array}{l}\text { Bruno and } \\
\text { Falzoni (2000) }\end{array}$ & $\begin{array}{l}\text { Employment } \\
\text { in parent, } \\
\text { affiliates in } \\
\text { Canada, } \\
\text { Latin- } \\
\text { America and } \\
\text { the rest of the } \\
\text { world }\end{array}$ & USA, 1982-1994, & 25 sectors & $\begin{array}{l}\text { Dynamic model that } \\
\text { includes adjustment costs } \\
\text { to consider that produc- } \\
\text { tion allocation may take } \\
\text { time; 4-equation system } \\
\text { estimated with GMM } \\
\text { (Arellano-Bond method) }\end{array}$ & $\begin{array}{l}\text { Employment in Canada and Latin American affiliates } \\
\text { is quasi-fixed due to adjustment costs. } \\
\text { Due to adjustment costs, employment of US parent and } \\
\text { employment of Latin-American affiliates are substi- } \\
\text { tutes in the short-run, but complements in the long run: } \\
\text { vertical division of activities between parent and affili- } \\
\text { ates. } \\
\text { Labour substitution dominates both in the sort- and } \\
\text { long run between locations in America and Europe: } \\
\text { proximity to final markets matters for location }\end{array}$ \\
\hline $\begin{array}{l}\text { Brainard and } \\
\text { Riker (1997) }\end{array}$ & $\begin{array}{l}\text { Factor cost } \\
\text { shares }\end{array}$ & $\begin{array}{l}\text { USA, 1982-1992, } \\
\text { manufacturing }\end{array}$ & $\begin{array}{l}70000 \text { firm- } \\
\text { country-time } \\
\text { observations }\end{array}$ & $\begin{array}{l}\text { System of factors cost } \\
\text { share equations were } \\
\text { estimation to derive the } \\
\text { elasticities of substitution } \\
\text { between employment at } \\
\text { different locations, SUR } \\
\text { estimation }\end{array}$ & $\begin{array}{l}\text { Strong substitution between affiliates at different low- } \\
\text { wage locations, but only moderate substitution between } \\
\text { US employment and employment of affiliates abroad: } \\
\text { vertical distribution of activities between countries } \\
\text { with different factor proportions (income levels) }\end{array}$ \\
\hline $\begin{array}{l}\text { Barba } \\
\text { Navaretti, } \\
\text { Castellani and } \\
\text { Disdier (2006) }\end{array}$ & $\begin{array}{l}\text { Employment } \\
\text { growth }\end{array}$ & $\begin{array}{l}\text { Italy and France, } \\
1993-2001\end{array}$ & $\begin{array}{l}\text { Different num- } \\
\text { bers, as effects of } \\
\text { different sub- } \\
\text { groups of OFDI } \\
\text { are studied; down } \\
\text { to } 41-97 \text { observa- } \\
\text { tions }\end{array}$ & PSM, PSM with DID & $\begin{array}{l}\text { No evidence of a negative effect of outward invest- } \\
\text { ments to cheap labour countries; in Italy OFDI en- } \\
\text { hances efficiency of home activities, in France a posi- } \\
\text { tive effect on the size of domestic activity is found } \\
\text { (scale effect) but not on productivity. Investments in } \\
\text { other developed countries:a positive impact due to the } \\
\text { scale effect if PSM and DID are used together. }\end{array}$ \\
\hline $\begin{array}{l}\text { Barba Navaretti } \\
\text { and Castellani } \\
(2004)\end{array}$ & $\begin{array}{l}\text { Employment } \\
\text { growth }\end{array}$ & $\begin{array}{l}\text { Italy, 1993-1997, } \\
\text { firms with at least } 20 \\
\text { employees }\end{array}$ & 119 firms & $\begin{array}{l}\text { PSM, PSM with DID, } \\
\text { conditional PSM, condi- } \\
\text { tional PSM with DID }\end{array}$ & $\begin{array}{l}\text { No effect of OFDI on employment growth; a positive } \\
\text { effect only in the case of simple PSM, but no effect if } \\
\text { DID approach is added or in the case of 'conditional' } \\
\text { PSM }\end{array}$ \\
\hline
\end{tabular}




\begin{tabular}{|c|c|c|c|c|c|}
\hline Author(s) & $\begin{array}{l}\text { Dependent } \\
\text { variable }\end{array}$ & $\begin{array}{l}\text { Data (Home coun- } \\
\text { try, period, sector) }\end{array}$ & $\begin{array}{l}\text { No of treatment } \\
\text { observations/ } \\
\text { sample size }\end{array}$ & Methods & Main results \\
\hline $\begin{array}{l}\text { Feenstra and } \\
\text { Hanson (1996) }\end{array}$ & $\begin{array}{l}\text { Change in the } \\
\text { wage share of } \\
\text { non- } \\
\text { production } \\
\text { workers }\end{array}$ & $\begin{array}{l}\text { USA, 1972-1990, } \\
\text { manufacturing }\end{array}$ & $\begin{array}{l}450 \text { 4-digit manu- } \\
\text { facturing indus- } \\
\text { tries }\end{array}$ & $\begin{array}{l}\text { Change in non- } \\
\text { production wage share } \\
\text { regressed on change in } \\
\text { outsourcing, output and } \\
\text { capital-to-output ratio, } \\
\text { OLS }\end{array}$ & $\begin{array}{l}\text { Outsourcing explains a significant share of the increase } \\
\text { in the non-production wage share in manufacturing - } \\
\text { outsourcing diminishes the demand for unskilled la- } \\
\text { bour in the USA }\end{array}$ \\
\hline $\begin{array}{l}\text { Braconier and } \\
\text { Ekholm (2000) }\end{array}$ & $\begin{array}{l}\text { Employment } \\
\text { of parent and } \\
\text { affiliates }\end{array}$ & $\begin{array}{l}\text { Sweden, 1970-1994, } \\
\text { manufacturing }\end{array}$ & $\begin{array}{l}\text { About } 700 \text { at firm } \\
\text { level, } 3000 \text { at } \\
\text { affiliate level }\end{array}$ & $\begin{array}{l}\text { Static labour demand } \\
\text { equations, regressors } \\
\text { include wages in home } \\
\text { and host country, in high } \\
\text { and low income locations } \\
\text { of the multinational }\end{array}$ & $\begin{array}{l}\text { Substitution is found between parent firm employment } \\
\text { and employment of subsidiaries in high-income coun- } \\
\text { tries, but no relationship between parent employment } \\
\text { and employment of subsidiaries located in low-income } \\
\text { countries; high trade costs with low-wage countries } \\
\text { could be an explanation }\end{array}$ \\
\hline $\begin{array}{l}\text { Amiti and Wei } \\
(2005)\end{array}$ & $\begin{array}{l}\text { Industry em- } \\
\text { ployment } \\
\text { growth at } \\
\text { home country }\end{array}$ & $\begin{array}{l}\text { UK, 1995-2001, } \\
\text { manufacturing and } \\
\text { services }\end{array}$ & $\begin{array}{l}69 \text { manufacturing } \\
\text { industries, } 9 \text { ser- } \\
\text { vice industries }\end{array}$ & $\begin{array}{l}\text { Employment growth } \\
\text { regressed on changes in } \\
\text { wages, value added, } \\
\text { service and material } \\
\text { outsourcing intensity }\end{array}$ & Job growth is not related to service outsourcing \\
\hline $\begin{array}{l}\text { Mariotti, Mu- } \\
\text { tinelli and } \\
\text { Piscitello } \\
\text { (2003) }\end{array}$ & $\begin{array}{l}\text { Regional } \\
\text { industry em- } \\
\text { ployment } \\
\text { growth in } \\
\text { home country }\end{array}$ & $\begin{array}{l}\text { Italy, 1985-1995, } \\
\text { manufacturing }\end{array}$ & $\begin{array}{l}180 \text { regional in- } \\
\text { dustries }\end{array}$ & $\begin{array}{l}\text { Employment growth } \\
\text { regressed on the change } \\
\text { of value added and the } \\
\text { change of employees in } \\
\text { foreign affiliates, OLS }\end{array}$ & $\begin{array}{l}\text { Vertical outward FDI in low-cost countries reduces } \\
\text { labour intensity of domestic production, horizontal and } \\
\text { market-seeking outward FDI in advanced countries } \\
\text { increases labour intensity of home-country production }\end{array}$ \\
\hline $\begin{array}{l}\text { Konings and } \\
\text { Murphy (2001) }\end{array}$ & $\begin{array}{l}\text { Parent em- } \\
\text { ployment }\end{array}$ & $\begin{array}{l}\text { European MNE's and } \\
\text { their subsidiaries, } \\
\text { 1994-1998, manufac- } \\
\text { turing and services }\end{array}$ & 1200 firms & $\begin{array}{l}\text { Employment regressed } \\
\text { on output, parent and } \\
\text { subsidiary wages, fixed } \\
\text { effects and Arellano- } \\
\text { Bond method }\end{array}$ & $\begin{array}{l}\text { Employment relocation occurs between the parent and } \\
\text { EU-based subsidiaries (but not subsidiaries in CEE } \\
\text { countries); relocation takes place in manufacturing but } \\
\text { not in services }\end{array}$ \\
\hline $\begin{array}{l}\text { Lipsey, Ram- } \\
\text { stetter, Bol- } \\
\text { ström }(2000) \\
\end{array}$ & $\begin{array}{l}\text { Number of } \\
\text { employees }\end{array}$ & $\begin{array}{l}\text { Japan, 1986, 1989, } \\
\text { 1992, manufacturing }\end{array}$ & NA & $\begin{array}{l}\text { Employment regressed } \\
\text { on value added of parent } \\
\text { and affiliates, OLS, }\end{array}$ & $\begin{array}{l}\text { Positive home-country effect in most industries, ex- } \\
\text { plained by additional ancillary employment at home } \\
\text { needed to service foreign operations }\end{array}$ \\
\hline
\end{tabular}




\begin{tabular}{|c|c|c|c|c|c|}
\hline Author(s) & $\begin{array}{l}\text { Dependent } \\
\text { variable }\end{array}$ & $\begin{array}{l}\text { Data (Home coun- } \\
\text { try, period, sector) }\end{array}$ & $\begin{array}{l}\text { No of treatment } \\
\text { observations/ } \\
\text { sample size }\end{array}$ & Methods & Main results \\
\hline $\begin{array}{l}\text { Blomström, } \\
\text { Fors and Lipsey } \\
\text { (1997) }\end{array}$ & $\begin{array}{l}\text { Parent em- } \\
\text { ployment }\end{array}$ & $\begin{array}{l}\text { USA: 1989, manufac- } \\
\text { turing } \\
\text { Sweden: 1970-1994, } \\
\text { manufacturing }\end{array}$ & $\begin{array}{l}\text { USA: } 1104 \text { firms } \\
\text { Sweden: } 637 \\
\text { firms }\end{array}$ & $\begin{array}{l}\text { Employment regressed } \\
\text { on sales of parent and } \\
\text { affiliates, OLS }\end{array}$ & $\begin{array}{l}\text { USA: negative home-country effect, MNEs have allo- } \\
\text { cated labour-intensive operations to affiliates in less } \\
\text { developed countries } \\
\text { Sweden: OFDI increases home employment at given } \\
\text { parent production due to the necessary auxiliary em- } \\
\text { ployment at home that serves foreign operations }\end{array}$ \\
\hline $\begin{array}{l}\text { Abraham, } \\
\text { Konings (1999) }\end{array}$ & $\begin{array}{l}\text { Parent em- } \\
\text { ployment }\end{array}$ & $\begin{array}{l}\text { Belgium, 1990-1995, } \\
\text { mostly manufacturing } \\
\text { but also services } \\
\text { firms }\end{array}$ & 152 firms & $\begin{array}{l}\text { Static labour demand } \\
\text { equation estimated with } \\
\text { OLS; extra variables are } \\
\text { dummies for foreign } \\
\text { competition, firms hav- } \\
\text { ing production facilities } \\
\text { in CEE }\end{array}$ & $\begin{array}{l}\text { Increased foreign competition hurts small, but not large } \\
\text { firms; presence of production facilities in CEE has no } \\
\text { effect on the parent's labour demand at home. } \\
\text { The main motive for Belgian companies to invest in } \\
\text { CEE is market entry, not use of cheap labour }\end{array}$ \\
\hline
\end{tabular}

Source: The authors' compilations based on the sources indicated in the table.

Notes. The abbreviations and acronyms used in the table: PSM - propensity score matching; DID - difference-in-difference. 


\section{Appendix 2. Summary statistics of regressors used in the employment growth model and probit model for new outward investments}

\begin{tabular}{|c|c|c|c|c|c|c|}
\hline Variable name & Variable definition & Mean & $\begin{array}{l}\text { Std. } \\
\text { Dev. }\end{array}$ & $\begin{array}{r}\text { Coefficient } \\
\text { of variation }\end{array}$ & Min & Max \\
\hline Employment growth & $\begin{array}{l}\text { The logarithmic em- } \\
\text { ployment growth rate }\end{array}$ & 0.01 & 0.43 & 30.47 & -8.19 & 8.19 \\
\hline Firm's size & $\begin{array}{l}\text { Firm's number of em- } \\
\text { ployees }\end{array}$ & 14.06 & 94.84 & 6.75 & 0.00 & 20040.00 \\
\hline Firm's age & $\begin{array}{l}\text { The annual average } \\
\text { growth rate of firm since } \\
\text { entry }\end{array}$ & 4.70 & 3.19 & 0.68 & 1.00 & 16.00 \\
\hline Wage cost per employee & $\begin{array}{l}\text { Average wage costs } \\
\text { divided by the total } \\
\text { number of employees } \\
\text { (euro) }\end{array}$ & 2321.68 & 4143.75 & 1.78 & 0.00 & 856452.70 \\
\hline Capital intensity & $\begin{array}{l}\text { The ratio of fixed assets } \\
\text { to the number of em- } \\
\text { ployees ('000 euro) }\end{array}$ & 10.56 & 154.07 & 14.60 & -8.23 & 28829.68 \\
\hline Labour productivity & $\begin{array}{l}\text { The ratio of value added } \\
\text { to employees (' } 000 \text { euro) }\end{array}$ & 8.90 & 36.33 & 4.08 & 0.00 & 6927.21 \\
\hline Export dummy & $\begin{array}{c}\text { Dummy, } 1 \text { if firm has } \\
\text { positive exports }\end{array}$ & 0.15 & 0.35 & 2.40 & 0.00 & 1.00 \\
\hline Foreign firm & $\begin{array}{c}\text { Dummy, } 1 \text { if foreign- } \\
\text { owned firm }\end{array}$ & 0.07 & 0.26 & 3.53 & 0.00 & 1.00 \\
\hline Outward FDI & $\begin{array}{c}\text { Dummy, } 1 \text { if firm has } \\
\text { outward FDI }\end{array}$ & 0.00 & 0.07 & 14.44 & 0.00 & 1.00 \\
\hline State firm & $\begin{array}{c}\text { Dummy, } 1 \text { if state- } \\
\text { owned firm }\end{array}$ & 0.01 & 0.10 & 10.04 & 0.00 & 1.00 \\
\hline Equity/Assets & $\begin{array}{c}\text { Shareholders' equity / } \\
\text { total assets }\end{array}$ & 0.36 & 1.15 & 3.20 & -24.36 & 1.00 \\
\hline Profit/Sales & $\begin{array}{l}\text { The ratio of operating } \\
\text { profit to sales }\end{array}$ & -0.06 & 0.82 & -14.43 & -14.09 & 3.87 \\
\hline
\end{tabular}

Note. The number of observations in the dataset is 414076 and the number of firms is 87310 .

The Estonian kroon is fixed to the euro at the rate of $1 \mathrm{EEK}=15.6466$ euros. All monetary values are in the 2001 prices. 
Appendix 3. Testing for the balancing property by testing for difference in means: the service sector, 2000-2002

\begin{tabular}{|c|c|c|c|c|c|c|c|}
\hline Variable & Sample & $\begin{array}{c}\text { Mean in } \\
\text { the } \\
\text { group of } \\
\text { treated }\end{array}$ & $\begin{array}{c}\text { Mean in } \\
\text { the con- } \\
\text { trol } \\
\text { group }\end{array}$ & $\begin{array}{l}\text { Percent } \\
\text { of bias }\end{array}$ & $\begin{array}{c}\text { Percentage } \\
\text { reduction } \\
\text { in bias }\end{array}$ & $\begin{array}{l}\text { Test for } \\
\text { the differ- } \\
\text { ences in } \\
\text { means }\end{array}$ & P-value \\
\hline \multirow[t]{2}{*}{ Log size $(-1)$} & Unmatched & 2.64 & 1.72 & 86.30 & & 7.64 & 0.00 \\
\hline & Matched & 2.64 & 2.73 & -8.90 & 89.70 & -0.52 & 0.60 \\
\hline \multirow[t]{2}{*}{ Log age } & Unmatched & 0.54 & 0.49 & 14.20 & & 1.28 & 0.20 \\
\hline & Matched & 0.54 & 0.54 & -0.60 & 95.60 & -0.04 & 0.97 \\
\hline \multirow[t]{2}{*}{ Log labour productivity $(-1)$} & Unmatched & 12.43 & 11.30 & 117.10 & & 9.56 & 0.00 \\
\hline & Matched & 12.43 & 12.43 & 0.50 & 99.50 & 0.04 & 0.97 \\
\hline \multirow[t]{2}{*}{ Foreign firm $(-1)$} & Unmatched & 0.29 & 0.08 & 55.50 & & 7.03 & 0.00 \\
\hline & Matched & 0.29 & 0.27 & 3.80 & 93.10 & 0.20 & 0.84 \\
\hline \multirow[t]{2}{*}{ Export dummy (-1) } & Unmatched & 0.56 & 0.19 & 83.10 & & 8.73 & 0.00 \\
\hline & Matched & 0.56 & 0.57 & -3.20 & 96.20 & -0.19 & 0.85 \\
\hline \multirow[t]{2}{*}{ Log capital intensity (-1) } & Unmatched & 11.26 & 9.99 & 77.50 & & 7.12 & 0.00 \\
\hline & Matched & 11.26 & 11.22 & 2.90 & 96.20 & 0.19 & 0.85 \\
\hline \multirow{2}{*}{$\begin{array}{l}\text { Log wage cost per employee } \\
(-1)\end{array}$} & Unmatched & 11.18 & 10.14 & 128.30 & & 11.42 & 0.00 \\
\hline & Matched & 11.18 & 11.16 & 3.30 & 97.50 & 0.23 & 0.82 \\
\hline \multirow[t]{2}{*}{ Equity/Assets(-1) } & Unmatched & 0.35 & 0.33 & 3.20 & & 0.23 & 0.82 \\
\hline & Matched & 0.35 & 0.37 & -4.30 & -35.20 & -0.41 & 0.68 \\
\hline \multirow[t]{2}{*}{ Profit/Sales (-1) } & Unmatched & 0.03 & -0.06 & 2.20 & & 0.14 & 0.89 \\
\hline & Matched & 0.03 & 0.08 & -1.00 & 52.20 & -1.45 & 0.15 \\
\hline
\end{tabular}




\section{DAVIDSON INSTITUTE WORKING PAPER SERIES - Most Recent Papers}

The entire Working Paper Series may be downloaded free of charge at: www.wdi.umich.edu

CURRENT AS OF 05/14/07

\begin{tabular}{|c|c|c|}
\hline Publication & Authors & Date \\
\hline $\begin{array}{l}\text { No. 873: The Impact of Outward FDI on Home-Country } \\
\text { Employment in a Low-Cost Transition Economy }\end{array}$ & $\begin{array}{l}\text { Jaan Masso, Urmas Varblane and } \\
\text { Priit Vahter }\end{array}$ & May 2007 \\
\hline $\begin{array}{l}\text { No. 872: Local Distributional Effects of Government Cash Transfers in } \\
\text { Chile }\end{array}$ & $\begin{array}{l}\text { Claudio A. Agostini and Philip } \\
\text { Brown }\end{array}$ & May 2007 \\
\hline $\begin{array}{l}\text { No. 871: How do Workers Fare During Transition?Perceptions of Job } \\
\text { Insecurity among Russian Workers, 1995-2004 }\end{array}$ & $\begin{array}{l}\text { Susan J. Linz and Anastasia } \\
\text { Semykina }\end{array}$ & April 2007 \\
\hline $\begin{array}{l}\text { No. 870: Does Reform Work? An Econometric Examination of the } \\
\text { Reform-Growth Puzzle }\end{array}$ & Ian Babetskii and Nauro Campos & April 2007 \\
\hline No. 869: Perceptions and Behavior: Analyzing Wage Arrears in Russia & $\begin{array}{l}\text { Susan Linz, Anastasia Semykina } \\
\text { and Charles Petrin }\end{array}$ & June 2006 \\
\hline $\begin{array}{l}\text { No. 868: The Endogeneity of Association Agreements and their Impact } \\
\text { on Trade for Eastern Countries: Empirical Evidence for Romania }\end{array}$ & $\begin{array}{l}\text { Christophe Rault, Ana Maria Sova } \\
\text { and Robert Sova }\end{array}$ & April 2007 \\
\hline $\begin{array}{l}\text { No. 867: Institutions \& Entrepreneurship Development in Russia: A } \\
\text { Comparative Perspective }\end{array}$ & $\begin{array}{l}\text { Saul Estrin, Ruta Aidis and } \\
\text { Tomasz Mickiewicz }\end{array}$ & Feb 2007 \\
\hline No. 866: Dutch Disease Scare in Kazakhstan: Is it real? & Balázs Égert and Carol S. Leonard & $\begin{array}{l}\text { March } \\
2007\end{array}$ \\
\hline $\begin{array}{l}\text { No. 865: Minimum Wage and Tax Evasion: Theory } \\
\text { and Evidence }\end{array}$ & Mirco Tonin & Jan 2007 \\
\hline $\begin{array}{l}\text { No. 864: Dynamics of the Financial Wealth of the Institutional Sectors in } \\
\text { Bulgaria: Empirical Studies of the Post-Communist Period }\end{array}$ & $\begin{array}{l}\text { Nikolay Nenovsky and Gergana } \\
\text { Mihaylova }\end{array}$ & $\begin{array}{l}\text { March } \\
2007\end{array}$ \\
\hline $\begin{array}{l}\text { No. 863: Impact of Derivatives Trading on Emerging Capital Markets: A } \\
\text { Note on Expiration Day Effects in India }\end{array}$ & $\begin{array}{l}\text { Sumon Kumar Bhaumik and } \\
\text { Suchismita Bose }\end{array}$ & $\begin{array}{l}\text { March } \\
2007\end{array}$ \\
\hline $\begin{array}{l}\text { No. 862: Short- \& Medium- Term Determinants of Current Account } \\
\text { Balances in Middle East \& North Africa Countries }\end{array}$ & Aleksander Aristovnik & $\begin{array}{c}\text { March } \\
2007\end{array}$ \\
\hline $\begin{array}{l}\text { No. 861: Time-Varying Comovements in Developed and Emerging } \\
\text { European Stock Markets: Evidence from Intraday Data }\end{array}$ & Balázs Égert and Evžen Kočenda & $\begin{array}{c}\text { March } \\
2007\end{array}$ \\
\hline $\begin{array}{l}\text { No: 860: Giving Children a Better Start: Preschool Attendance \& } \\
\text { School-Age Profiles }\end{array}$ & $\begin{array}{l}\text { Sam Berlinski, Sebastian Galiani } \\
\text { and Marco Manacorda }\end{array}$ & Jan 2007 \\
\hline $\begin{array}{l}\text { No. 859: Real Exchange Rates in Small open OECD \& Transition } \\
\text { Economies: Comparing Apples with Oranges? }\end{array}$ & $\begin{array}{l}\text { Balázs Égert, Kirsten } \\
\text { Lommatzsch and Amina } \\
\text { Lahreche-Revil }\end{array}$ & Jan 2007 \\
\hline $\begin{array}{l}\text { No. 858: Is Education the Panacea for Economic Deprivation of } \\
\text { Muslims? Evidence from Wage Earners in India, 1987-2004 }\end{array}$ & $\begin{array}{l}\text { Sumon Kumar Bhaumik and } \\
\text { Manisha Chakrabarty }\end{array}$ & Jan 2007 \\
\hline $\begin{array}{l}\text { No. 857: Human Capital, Economic Growth, and Regional Inequality in } \\
\text { China }\end{array}$ & $\begin{array}{l}\text { Belton Fleisher, Haizheng Li and } \\
\text { Min Qiang Zhao }\end{array}$ & Jan 2007 \\
\hline $\begin{array}{l}\text { No. 856: Does Better Environmental Performance Affect Revenues, } \\
\text { Costs, or Both? Evidence From a Transition Economy }\end{array}$ & $\begin{array}{l}\text { Dietrich Earnhart and Lubomir } \\
\text { Lizal }\end{array}$ & Feb 2007 \\
\hline No. 855: Media Coverage \& Charitable Giving After the 2004 Tsunami & Philip Brown and Jessica Minty & Dec 2006 \\
\hline $\begin{array}{l}\text { No. 854: Default Rates in the Loan Market for SMEs: Evidence from } \\
\text { Slovakia }\end{array}$ & $\begin{array}{l}\text { Jarko Fidrmuc, Christa Hainz and } \\
\text { Anton Maleisch }\end{array}$ & Nov 2006 \\
\hline $\begin{array}{l}\text { No. 853: Monetary Policy before Euro Adoption: Challenges for EU } \\
\text { New Members }\end{array}$ & $\begin{array}{l}\text { Jan Filáček, Roman Horváth and } \\
\text { Michal Skorepa }\end{array}$ & Nov 2006 \\
\hline $\begin{array}{l}\text { No. 852: Private-Sector Credit in Central \& Eastern Europe: New } \\
\text { (Over) Shooting Stars? }\end{array}$ & $\begin{array}{l}\text { Balázs Égert, Peter Backé and } \\
\text { Tina Zumer }\end{array}$ & Nov 2006 \\
\hline $\begin{array}{l}\text { No. 851: Interest Rate Pass-Through in Central \& Eastern Europe: } \\
\text { Reborn from Ashes Merely to Pass Away? }\end{array}$ & $\begin{array}{l}\text { Balázs Égert,Jesus Crespo- } \\
\text { Cuaresma and Thomas Reininger }\end{array}$ & Nov 2006 \\
\hline $\begin{array}{l}\text { No. 850: Monetary Transmission Mechanism in Central \& Eastern } \\
\text { Europe: Gliding on a Wind of Change }\end{array}$ & $\begin{array}{l}\text { Fabrizio Coricelli, Balázs Égert } \\
\text { and Ronald MacDonald }\end{array}$ & Nov 2006 \\
\hline
\end{tabular}

